\title{
Cankar i Andrić - Osvrt na upotrebu poređenja i nekoliko odabranih izraza
}

\author{
Zdravko Šolak"
}

\begin{abstract}
$^{1}$
The paper focuses on the examples of comparison constructions appearing in the collected works of Ivan Cankar i Ivo Andrić containing expressions such as 'as/like petrified', 'as/like struck down', 'as/like wounded', , 'as/like dead'. Another focus is also on comparisons revolving around nouns such as 'funeral' and 'grave', as well as on some other idiosyncratic comparison constructions (including 'writhe like a worm', 'rattle like a grandma', 'like the plague in the house'). Additional expressions centring on the description of the colour of ones face (i.e. pale or green face, colourless face, face of unhealthy colour, dead man's pale face), centring on the concept of something being made of one piece only, something illuminated from within, and something being taken using both hands. A common denomination of the observed expressions is their infrequent use since both of the writers at hand limit their employment to one use only per one piece of writing. Also, both Cankar and Andrić use these somparisons in situations in which something is unfavorable, uncertain, or risky for a particular character. Moreover, the istances of use of these partcular comparison constructions have further been illustrated by their appearance in the writings of other South Slavic and Russian authors (which also helps us underlie the most typical verbs used to support these comparisons).
\end{abstract}

Key words: Ivan Cankar, Ivo Andrić, South Slavic authors, Russian classical literature, comparison

\footnotetext{
* Visoka poslovna škola Novi Sad, Srbija

1 Posebnu zahvalnost dugujem svima koji su mi omogućili neophodne usluge i sve pogodnosti u pogledu korišcenja fonda u Biblioteci Matice srpske u Novom Sadu. Takođe sam nailazio na izuzetnu predusretljivost zaposlenih u Gradskoj biblioteci u Novom Sadu, kao i Narodnoj biblioteci iz Surdulice. Za podršku koju su mi pružili tokom rada takođe zahvaljujem Radojki Jakšić, Đorđu Ćuzoviću, Slaviši Đukanoviću, Dobrivoju Majkiću, Novici Pavloviću.
} 


\section{Uvod}

Časopis Književni jug iz svoje redakcije u Zagrebu objavio je povodom smrti slovenačkog pisca Ivana Cankara (1876-1918) saopštenje: „Njegova smrt ne znači gubitak smo za Sloveniju već za čitavu Jugoslaviju, jer je njegov Duh bio svojina i ponos svih nas“2. Te godine kada se Cankarev život završio, Ivo Andrić (1892-1975), jedan od članova redakcije Knjižeonog juga, tek je bio objavio Ex ponto, svoju prvu knjigu. Andrić je još u mladim danima u svoju biografiju počeo da unosi znanje slovenačkog jezika. Cankar je nekoliko meseci 1910. godine boravio u Sarajevu u vreme dok je Andrić u tom gradu pohađao gimnaziju, pa su tako, $u$ isto vreme, u jednom periodu svog života, oba pisca mogli da posmatraju društvena zbivanja na Balkanu iz istog mesta. Tokom godina školovanja i jedan i drugi proveo je neko vreme u Beču. I jedan i drugi pisao je o pesniku Gabrijelu D’Anunciju (1863-1939), o sarajevskim grobljima, objavio prozu „Gospođica“, „Ispovijed“. Cankar je visoko cenio delo Fjodora Dostojevskog. ${ }^{3}$ I Andrić je o Dostojevskom govorio kao o velikom piscu. ${ }^{4}$ Podržavali su jugoslovenstvo i bili zatvarani zbog svojih političkih ideja. Već u mladim godinama imali su ozbiljnih problema sa zdravljem. Bolest, kojoj je Andrić u mladosti odoleo, Ivanu Cankaru skratila je životni vek. Podudarnostima iz njihovih biografija moguće je dodati i jednu koja se odnosi na samo njihovo delo, na odliku tehnike pripovedanja. U njihovoj prozi često se javlja poređenje.

U ovom osvrtu na njihovo književno delo u obzir je uzeta upotreba poređenja i nekih odabranih izraza. Primeri upotrebe pojedinih izraza, prema preliminarnoj široj listi, izdvajani su njihovih sabranih dela. (Pod primerom je podrazumevan deo teksta u kojem se javlja posmatrani izraz, poređenje ili karakteristično zapažanje o nekoj pojavi.) Ako se neki karakterističan izraz javljao na više mesta u piščevom delu težilo se izdvajanju što većeg broja primera i što potpunijem obuhvatu. Za upoređenje su takođe izdvajani i primeri iz dela ruske klasične književnosti, kao i primeri iz dela južnoslovenskih pisaca. Pisci čija su dela poslužila kao izvor rođeni su u devetnaestom veku (prilog 1 na kraju rada).

Pojedini istraživači primenjivali su razne načine klasifikacije poređenja. Pri klasifikaciji poređenja izdvojenih iz Cankarevog i Andrićevog dela uzeli smo u obzir frekventnost javljanja u njihovim pričama i romanima. U ovom članku bavimo se poređenjima koja nisu učestala. (Ostaje da se frekventna i hipotetična poređenja izlože u posebnom tekstu.) Neki od izraza kojima se ovde bavimo sadržani su i u monografijama i reč-

2 Cankar je umro 11. decembra 1918. godine. Saopštenje je objavljeno u prvoj svesci časopisa 1919. godine (Književni jug 1919, 1: 40)

3 Zapažanja o ruskim piscima Gogolju, Turgenjevu, Dostojevskom i Tolstoju Ivan Cankar naveo je u pismu Izidoru Cankaru 13. avgusta 1906. godine. Videti: Cankar, Izidor (1968) Leposlovje, eseji, kritika. Prva knjiga, Ljubljana, str. 140.

4 U knjizi Sa Ivom Andrićem naveden je Andrićev komentar: „Za mene su Fjodor Dostojevski i Tomas Man dve najkrupnije književne figure na razmeđi devetnaestog i dvadesetog veka; sa njima je počela evropska književnost“ (Jandrić 1977: 152) 
nicima iz slovenske frazeologije (Телия 1996; Ничева 2002; Nedokova 2011; Keber 2011; Otašević 2012). Na komentare iz tih priručnika obično smo se osvrtali kratkim napomenama.

I drugi autori upoređivali su Ivana Cankara sa piscima realistima (Kraft 1969; Đukić 1977; Ožbalt 1978; Nabergoj 2015). Upoređujući njegovo delo s delom Ive Andrića ovde imamo u vidu tehniku pripovedanja, postupak koji je dolazio do izražaja u tekstu čija dužina nije velika. Izlaganje je raspoređeno u tri dela. U prvom delu bavimo se izrazima upotrebljenim u slikovitom opisu lika u situaciji koja se naglo promenila. U drugom delu rada reč je o izrazima upotrebljenim u opisu ljudskog lica, U trećem je učinjen osvrt na upotrebu nekoliko odabranih izraza.

\section{Lik u naglo izmenjenoj situaciji}

Nagle promene ponašanja u različitim situacijama u koje dospevaju likovi u pojedinim etapama događaja o kojima se pripoveda i Cankar i Andrić često su opisivali upotrebom slikovitih izraza. U pitanju je promena izazvana nepovoljnim razrešenjem okolnosti u kojima se jedna osoba nalazila. Karakterističan je nagli obrt koji često zatiče čoveka nespremnim da prihvati razvoj situacije i čini ga nemoćnim da preduzme neku akciju. Oni koji se nalaze u blizini takve osobe lako prepoznaju nagle promene u njenom izgledu i ponašanju. U tabelama 1-12 navedeni su primeri kojima se ona slikovito opisuje upotrebom izraza: kao okamenjen, kao pokošen, kao ranjen, kao mrtav. ${ }^{5}$ To su poređenja. Za njihovu potpuniju ocenu često je neophodno uzeti u obzir širi kontekst, ponekad i priču u celini.

\subsection{Upotreba izraza „kao okamenjen“}

Upotreba izraza „kao okamenjen“ javlja se u opisu stanja u kojem se jedan lik našao zatečen. Ono što se upravo dogodilo, nepovoljno je za njega. Iznenađen je i treba mu neko vreme da se pribere. U primerima u tabeli $1^{6}$ izraz „kao okamenjen” upotrebljen je u opisu lika koji stoji. Izraz „стоял как окаменелый” nalazimo kod Tolstoja.?

\footnotetext{
5 U upotrebi su takođe i drugi izrazi: „kao ukopan“, „kao oparen“, „kao poliven“.

6 U levoj koloni tabele navedeni su primeri iz Cankarevog, a u desnoj iz Andrićevog dela. Tako je postupano i u drugim tabelama u ovom radu.

7 Володя стоял как окаменелый и не верил глазам своим. (Толстой 2009: 255)
} 
(1) Milena je stala sredi izbe napol oblečena, nepremična, kakor okamenela (20: 209)

(2) kadar pa jih zalotiš nenadoma, stojé pred obrazom kakor okameneli in se ne morejo geniti. (8: 229)

(3) Stal je pred. mano kakor okamenel [...]. (12: 56) $\left(1^{\circ}\right)$ Stojekao skamenjene, sa škrtom senkom pored sebe, nepomične. (10: 217)

$\left(2^{\circ}\right)$ nekoliko trenutaka čobani su stajali kao skamenjeni od čuda, ali onda su se pribrali. (9: 195)

$\left(3^{\circ}\right)$ Žene su stajale kao skamenjene. (9: 113)

1 - Milan i Milena, 2 - Kralj Malhus, 3 - Gospa Judit; $1^{\circ}$ - Španska stvarnost i prvi koraci u njoj, $2^{\circ}$ - Aska i vuk, $3^{\circ}-\mathrm{Zmija}$

Napomena: Primeri su izdvajani prema izdanjima sabraniih dela: Andrić (1978) Sabrana dela Ive Andrića, Prosveta, Beograd; Andrić (1981) Sabrana djela Ive Andrića, Svjetlost, Sarajevo; Cankar (1967-1976) Zbrana dela, Državna založba Slovenije, Ljubljana. Uz pojedine primere navedeni su knjiga u sabranim delima i broj strane u toj knjizi na kojoj se nalazi primer (knjiga: strana). Tako je postupano i u drugim tabelama u ovom radu.

Tabela 1: Upotreba izraza: „kao okamenjen“ uz glagol „stajati“

Izraz „kao okamenjen“ uz upotrebu glagola „stajati“ obično se navodi u opisu stanja koje ne traje dugo. Nalazimo i primere u kojima su okolnosti nešto duže potrajale. Trajanje tog vremena pisci ne određuju precizno, ali se iz samog opisa često stiče utisak da ono nije suviše dugo.

Ivan Cankar

Ivo Andrić

(1) Ko je ugledal župnika, je odprl usta in je obstal ob durih kakor okamenel. (16: 155)

(2) Ona je bila kakor okamenela; gledala me je pazno, z velikim pogledom [...]. (9: 242)

(3) Gradar se je vspel visoko ter obstal kakor okamenel. (7: 73)

(4) Ko je odprl duri, ga je udarilo od temena do nog - in stal je kakor okamenel. (17: 296)

(5) vsi, kolikor jih je bilo, [...] so bili kakor okameneli od pričakovanja (23: 167)

(6) kmetje so sedeli za mizo kakor okameneli (18: 26) $\left(1^{\circ}\right)$ Zato je i stajao tako jedno vreme, otvorenih usta, kao okamenjen. (15: 171)

$\left(2^{\circ}\right)$ Ljudi koji su ostali u ćeliji ćutali su još nekoliko trenutaka kao okamenjeni [...]. (10: 80)

$\left(3^{\circ}\right)$ Sve stalo kao skamenjeno i samo gleda u vis. (8: 291)

$\left(4^{\circ}\right)$ Ostali svati [...] ostali pored kamene ograde u čudnim položajima, kao skamenjeni. (1: 132)

$\left(5^{\circ}\right)$ Tu su čekale kao okamenjene i neosetljive za glad, žeđ i studen, [...]. (1: 25)

$\left(6^{\circ}\right)$ Sedele su skamenjene, kao da čekaju osudu, [...]. (1: 208)

1 - Polikrap, 2 - Smrt kontrolorja Stepnika, 3 - Nina Vinjete , 4 - Za križem, 6 -Kako se je useknil gospod Peter Mozolec, 5 - Sosed Luka; $1^{\circ}$ - Crveni cvet, $2^{\circ}-$ U ćeliji broj $115,3^{\circ}-$ Osatičani, $4^{\circ}, 5^{\circ}$ i $6^{\circ}-$ Na Drini ćuprija

Tabela 2: Upotreba izraza: „kao okamenjen“ 
U primerima $1-5$ i $1^{\circ}-5^{\circ}$ u tabeli 2 izraz „kao okamenjen“ javlja se u opisu ljudi koji nešto čekaju, u nešto gledaju, koji su nečim iznenađeni. Izraze „jedno vreme“, i „nekoliko trenutaka“ (primeri $3^{\circ}$ i $4^{\circ}$ ) upućuju na to da je situacija kratko trajala. Takav utisak čitalac će steći i ukoliko se u istoj rečenici opiše neka radnja koju lik tek počinje da obvlja. ${ }^{8}$ Cankar je opisujući seljake koji sede upotrebio izraz „kakor okameneli” (primer 6, tabela 2). U primeru $6^{\circ}$ izostavljena je poredbena rečca i upotrebljena u drugom delu rečenice u kojoj je reč o osobama koje sede.

U opisu ponašanja likova izraz „kao okamenjen“ rasprostranjen je u delima ruskih pisaca: Gogolja ${ }^{9}$, Turgenjeva ${ }^{10}$, Gončarova ${ }^{11}$, Dostojevskog ${ }^{12}$, Tolstoja ${ }^{13}$. Slična poređenja česta su i u delima južnoslovenskih pisaca. U frazeološkom rečniku bugarskog jezika navodi se da „като вкаменен“ uz glagole „stajati“, „gledati“ znači u stvari biti iznenađen, uplašen (Ничева 2002: 168). Primere takvi upotreba nalazimo u delima pisaca Vazova i Jovkova. ${ }^{14}$

8 Ciganka, koja je posle onog prvog strašnog vriska ostala kao skamenjena, počela je da nariče ponovo, [...]. (Andrić 1978 knj. 15: 148)

9 Как будто окаменев, не сдвинувшись с места, слушал Петро, [...]. (Гоголь 2009с: 61)

10 (1) Она вся словно окаменела; (2) Елена перешла в соседнюю комнату, прислонилась к стене и долго стояла как окаменелая (3) Сердце у меня словно окаменело и голова тоже, (Тургенев 2011а: 378; 2013: 58)

11 (1) Она осталась, как окаменелая, потом проворно позвонила. (2) она [...] остановилась как вкопанная, окаменелая, не дыша, в грозной позе, с грозным взглядом, вполуоборот. (Гончаров 2015: 750; 2012: 324)

12 (1) Митя молчал, как бы окаменев, опустив глаза в землю. (2) Мертвая тишина залы не прерывалась, буквально как бы все окаменели - и жаждавшие осуждения, и жаждавшие оправдания. (Достоевский 2012а: 923, 1021)

13 (1) Она слышала [...] но сидела, как окаменелая, не в силах ни начать говорить, ни встать. (2) Сказав это, она вздохнула, и лицо ее, вдруг приняв строгое выражение, как бы окаменело. (Толстой 2011b: 699, 907)

14 (1) Бръчков остана като вкаменен. (2) Но Варлаам стоеше като вкаменен и гледаше в носа на бея. (3) Вълкана остана като вкаменяла. (4) Бежанците се обърнаха и останаха като вкаменени. (5) Стремски остана като вкамънен. (Вазов 1956 том 5 136. 257; том 12: 339; том 13: 87); (6) Захари стоеше под покрива като вкаменен. (7) Те стояха настрана и не се помръдваха, като вкаменени (Йовков 1983 том 3: 197, 275) 
Ranković $^{15}$, Sremac ${ }^{16}$ i Matavulj ${ }^{17}$ bili su skloni upotrebi izraza „kao okamenjen“. Izdvojeni su i primeri iz dela drugih srpskih pisaca ${ }^{18}$, kao i primeri iz dela hrvatskih ${ }^{19}$ i slovenačkih pisaca. ${ }^{20} \mathrm{Za}$ onoga ko je stao (stoji) kao okamenjen moglo bi se reći i da nepomično stoji (Keber 2011: 627). Sličnu upotrebu ima i izraz „kao ukopan“. ${ }^{21}$

\subsection{Upotreba izraza „kao pokošen“, „kao ranjen“, „kao mrtav“}

Cankar i Andrić upotrebljavali su ove izraze u opisu situacije u kojoj je iznenadna promena imala odraza na fizičko stanje jedne osobe. U primerima navedenim u tabeli 3 izrazi „kao pokošen“, „kao ranjen“, „kao mrtav“ nalaze se u blizini glagola „pasti“ „vrisnuti“, „ležati“. Tako je pojačana slikovitost opisa nagle promene koja je nastupila u ponašanju lika kom se otkriva nešto novo, koji se našao pred nepovoljnim razrešenjem neke neizvesnosti.

15 (1) A Stanka [...] obori glavu na ruku i stade kao okamenjena [...] (2) Kad se isplaka, opet se zamisli i ostade dugo tako kao okamenjen [...] (3) Ljubica sedi na stolici kao okamenjena, čak joj i glava ostala još malo zaturena (4) Bogosav vidi da se ona ućutala kao okamenjena [...]. (5) Čim izađosmo na rudinu, stadosmo svi kao okamenjeni. (6) A mi svi besmo kao hladna, okamenjena, nepomična stena, [...]. (7) Kako je ko ugledao bolesnika, svaki je zastao kao okamenjen. (Ranković 1952 knj. 1: 193, 322, 329, 403; knj. 2: 298, 329, 402)

16 (1) gđa Persa na jedan mah preblede i kao okamenjena posmatraše gđu Sidu (2) Stala je kao okamenjena, pa nije znala ni reči da kaže. (3) oboje zastadoše kao okamenjeni, jer oboje spaziše u kolima pop-Spiru (4) slušao ga Mane koji je, kao skamenjen (Sremac 2011a: 76, 130; 2011b: 295)

17 (1) Nasta trenutak nijeme tišine; svi izgledahu kao skamenjeni (2) Kako razabra prve rïječi što ču, ustavi se kao skamenjen i poblijeđe. (3) [...] bi nas bila sve pobila, jer smo ja i gospodarica stajale kao skamenjene. (4) Onda oboje stadoše kao skamenjeni, posmatrajući tovar, magarca i kokoši. (5) Latini, kao skamenjeni od čuda i od divljenja pred tolikom vjerom i hrabrošću, pustiše starca s mirom (Matavulj 2006 knj. 1: 97, $371 ; 2007$ knj. 3: 262, 362, 403)

18 (1) On je stojao kao okamenjen pred tom svetom slikom domaćom [...] (2) Da ga on nije poveo, ostao bi na mestu kao okamenjen. (3) A on osta na mestu kao okamenjen od stida. (Veselinović 1983: 48, 54, 324); (4) Ali se trže od svog šapata i kao da se okameni nasred sobe. (5) [...] ali se ne makoh s mesta, i kao okamenjen gledah u majku. (Lazarević 2011: 61, 166); (6) Lesa se zaustavi kao okamenjena. (Uskoković 1995: 76), (7) Deca ukočila se kao okamenjena; (Ćipiko 1951 knj. 1: 182), (8) ona sama, ona sen, onako ukočena i kao okamenjena mrtva statua (9) Crkva, onako široka na stubovima, [...] izgledala je tako hladna, kao skamenjena. (10) odlazi ispred njega kao skamenjena, ubijena tugom, nesrećom. (Stanković 1966: 161; 1979: 121) (11) Sve se bilo kao skamenilo. (Crnjanski 2002 knj. 2: 239)

19 (1) Marijan se naglo okrenu i stane, kao da se je skamenio. (2) Starac i starica protrnuše i kao da seokameniše od čuda i gorke tuge. (3) osta kao okamenjena pred vratima sobe (Kumičić 1885: 216; $1950 \mathrm{knj}$. 1: 80, 200), (4) Naposljetku zaleti se starica na djevojku koja je stajala sveudilj kao okamenjena i ukopana [...]. (Đalski 1980: 88) (5) Hlapić je stajao kao okamenjen od čuda s papigom na ramenu (6) Vođ je stajao kao okamenjen. što za bure padne iz gnijezda. (7) pomislio je naglo i našao se s ledenom, kao okamenjenom dušom pred vratima dekanata (Novak 1951: 286), (8) Salko se kao skamenio i nije pritrkao k ocu da mu prihvati konja (Šimunović 1952 knj. 1: 141) (9) Ja sam ostala kao okamenjena, ja sam pridušeno uskliknula: ah! (Kozarac 1950: 408) (10) Mujo zuri preda se kao okamenjen. (Krleža 1973: 405), (11) Čuvši Mejra kobnu vijest, osta kao okamenjena. (12) Branimir stajaše kao okamenjen [...] (Tomić 1970: 79, 469)

20 (1) Zatoženec stoji za trenotek kakor okamenel, potem pa stopi bliže [...]. (2) Starka stoji za trenotek kakor okamenela in težka sapa jo premaguje. (3) V hiši nastane molk, kakor bi bili vsi okameneli [...]. (Kresnik 2012: 20, 14, 83), (4) Kakor okamenel obstane pastir [...]. (Jurčič 2012: 6) (5) Kakor okamenela je strmela v okno. (6) molčala je vsa hiša v težkem, morečem molku, kakor okamenela, izumrla, [...]. (7) Stala je za hip kakor okamenela, [...]. (Meško 1907: 56, 58, 64); (8) Stal je kakor tekalec, ki je okamenel sredi naglega, napetega teka. (Meško 1954: 80)

21 „stati (ostati i sl.) kao ukopan (okamenjen) - zastati, neglo se na mjestu zaustaviti (ukočiti) / od iznenađenja (straha)“ (Menac 2003: 324) 
(1) strinjale so se in razmikale, mahoma so padle na trebuh kakor pokošene (23: 40)

(2) A jaz sem bežal kakor ranjen [...]. (6: 300)

(3) Lena, kakor mrtva je ležala $v$ klopčič zvita. (24: 274) $\left(1^{\circ}\right)$ posle svakog dodira sa svetom padam kao pokošen i drhtim u bolu (14: 59)

$\left(2^{\circ}\right)$ Ona vrisnu kao ranjena. (7:235)

$\left(3^{\circ}\right)$ [Aska] je ležala u šumskoj travi kao mrtva. (9: 194)

1 - Podobe iz sanj, 2 - Moj prvi nastop, 3 - Bela hrizantena; $1^{\circ}-$ Znakovi pored puta, $2^{\circ}$ - Žena od slonove kosti, $3^{\circ}-$ Aska i vuk

Tabela 3: Upotreba izraza „kao pokošen“, „kao ranjen“, „kao mrtav“

Izraz „как подкошенный“ upotrebio je Dostojevski u romanima „Braća Karamazovi“ i „Zapisi iz mrtvog doma“.22 Uz izraz „kao pokošen“ ponekad se saopštava mesto. Svetolik Ranković je naveo da se pada na zemlju kao pokošen. Seda se i u klupu kao pokošen..$^{23}$ Neko „seda kao pokošen“, u fotelju, za sto. U primerima iz Andrićevog dela osoba koja sedi „kao pokošena“ teško se miri sa situacijom u kojoj se našla, ali još ima snage da nastavi prekinutu aktivnost, da piše ili da produži razgovor. ${ }^{24}$

Izraz „как раненый“ upotrebio je Dostojevski opisujući situaciju u kojoj jedan lik intenzivno reaguje. ${ }^{25}$ Gončarov je taj izraz upotrebio u kratkoj rečenici. ${ }^{26} \mathrm{U}$ delima južnoslovenskih pisaca uz izraz „kao ranjen“ karakteristična je upotreba odabranog glagola $\mathrm{u}$ istoj rečenici. $U$ primerima 2 i $2^{\circ}$ u tabeli 3 vidimo glagole,bežati“ $i$ „vrisnuti“. Andrić je upotrebio i glagol ,ječati“ imajući u vidu oglašavanje ranjenog. Sličnu ulogo dobili su i drugi glagoli: ,jeknuti““27, „ruknuti“28, „zastenjati““29, „zavrišstiti“, „zacviliti“,

22 (1) Старик рухнулся как подкошенный, а Дмитрий, перескочив через него, вломился в дверь. (2) Алеша стоял, смотрел и вдруг как подкошенный повергся на землю. (3) И как подкошенный сел, словно упал, на подле стоявший стул. (4) бедняк с криком упадает, как подкошенный, как сраженный пулей. (Достоевский 2012a: 189, 490, 599; 1988b: 381)

23 Pero sjede u klupu kao pokošen. (Lovrak 1989: 39)

24 (1) Piše, kao pokošen, sam svoju slabost i sramotu, [...]. (2) kapelan je ostajao [...] kao pokošen; (3) Nije venula polako, nego kao mrazom pokošena. (4) Seo sam kao pokošen, i poslednjim naporom snage prisilio starog čoveka da sedne i on [...]. (5) Tada je Karajan ostavio sve i seo u fotelju kao pokošen, onako u kaputu i sa šeširom na glavi, [...]. (Andrić 1978 knj. 2: 164, 213; knj. 4: 107; knj. 8; 97, Andrić 1981 knj.14: 218)

25 Орел защищался из всех сил [...] как раненый король, забившись в свой угол. Достоевский 1988a: 434)

26 Он встал, как раненый. (Гончаров 2015: 417)

27 Metnu ruku na oroz i jeknu, jeknu kao ranjen, i omače. (Humo 1955: 85)

$28 \mathrm{U}$ isti čas rukne Andraš kao ranjenik i zalijepi jednog seljaka o jedan zid, [...]. (Matoš 1953 knj. 1: 206)

29 [...] gusle zacvilješe i zastenjaše kao ranjenik. (Šimunović 1952 knj. 1:218) 
„zaridati“. ${ }^{30}$ Jakšićevom junaku preostalo je manje snage za akciju. ${ }^{31}$ Jedna osoba može da postupa sa drugom kao što se postupa s ranjenikom. ${ }^{32}$

Izraz „kao mrtav“ javlja se u opisu situacije u kojoj lik nije u stanju da ispolji ni najmanji pokret niti neku drugu uočljivu akciju. Privremeno isključen, on nije u stanju da stvara percepciju o spoljnjem svetu. U slikovitom opisu takvog stanja primere upotrebe izraza „как мертвый“ nalazimo kod Dostojevskog ${ }^{33}$ i Leskova ${ }^{34}$. Stanje u kom se lik našao može, pored ostalog, da bude i posledica umora, bolesti, udarca, upravo primljene neprijatne vesti. U primerima 3 i $3^{\circ}$ u tabeli 3 Cankar i Andrić su uz izraz „kao mrtav“ upotrebili glagol „ležati“. Izraz „kao mrtav“ upotrebljava se i uz glagol „spavati“. Javljanje izraza „kao mrtav“ rasprostranjeno je u književnim delima pisaca koje smo u ovom osvrtu imali u vidu. Upotrebili su ga: Ljermontov ${ }^{35}$, Gončarov ${ }^{36}$, Ranković ${ }^{37}$, Matavulj $^{38}$, Levstik ${ }^{39}$, Kumič ić $^{40}$, Brlić-Mažuranić ${ }^{41}$, Begović. ${ }^{42}$

\section{Promene na licu}

U opisu ponašanja pojedinih likova u situaciji u kojoj do izražaja dolazi psihološka napetost i Cankar i Andrić poseban značaj pridavali su opisu lica i vidljivim promenama na licu koje zapažaju ljudi iz neposrednog okruženja. Važan element tog opisa je i boja

30 Tuga, Zorka i Ančica zavrište, zacvile, zaridaju kao ranjene. (Kovačić 1983: 124)

31 posrnu jedanput, drugi put, pa, kao ono ranjen vitez, stropošta se na zemlju [...]. (Jakšić 1978 knj. 3: 93)

32 (1) Gospođica dođe pravo sebi i vide da je celom težinom naslonjena na Jovanku, koja je vodi zagrljenu kao ranjenika. (2) Ali veća i jača od svega bila je njena potreba da jauče nad svojim izgubljenim novcem [...] da ječi kao ranjenik. (Andrić $1978 \mathrm{knj}$. 3: 225, 230), (3) Tako govoreč ga je prijel pod pazduho kakor ranjenca ali pijanca [...]. ( Levstik 1934: 81)

33 (1) били много и долго и переставали только тогда, когда он терял все свои чувства и становился как мертвый. (Достоевский 1988b: 248), (2) [...] я пошла наверх, похолодев от испуга как мертвая. (3) Я, как услышала, побледнела и упала на стул как мертвая. (Достоевский 1998: 288, 181)

34 Настя долго оставалась без чувств, как мертвая. (Лесков 1973 том 1: 166)

35 [...] он никого не замечал; постояли, потолковали и пошли назад; я велел возле его положить деньги забаранов - он их не тронул, лежал себе ничком, как мертвый. (Лермонтов 1977: 37)

36 Она была бледна и спала, как мертвая. (Гончаров 1958: 631)

37 (1) ne mrdnu glavom, kao da je mrtav (2) oči joj se staklene i stoje nekako neobično kao da je mrtva (3) Gojko leži sam već čitav čas, ne mrda ničim, ne pokrete se, kao mrtvac [...] (Ranković 1952 knj. 1: 353, $382,385)$

38 turio pod glavu kamen [...] zagrlio vjernu drugu, dugačku pušku, pa - kao mrtav. (Matavulj 2006 knj. 1: 371)

39 Ded zleze s sani in stopi k lisici; toda ona se ne gane, kakor mrtva leži. (2) V tej podrtiji spi moja krasna gospa kakor mrtva, [...]. (Levstik 1924: 101, 118)

40 Ona se poda besvjesno, kao mrtva. (Kumičić 1950 knj. 1: 370)

41 Zavrisnuše djeca od straha i popadaše na zemlju kao mrtvi. (Brlić-Mažuranić 1926: 104)

42 (1) Ležao sam kao mrtav. Nepomoćan. (2) Izgledala je kao mrtva. (3) A stari kao mrtav. (Begović 1965 knj. 1: 327, 346; knj. 2: 127) 
(1) Brez klobnka je bil, ves bled in zelen $\mathbf{v}$ obraz, roke pa je imel zatekle. (19: 114)

(2) [...] njegov obraz je bil resen, bolj šrok, toda iste sive, nezdrave barve. (11: 127)

(3) V materinem naročju je ležal trileten otrok [...] njegov drobni obraz je bil sivkaste, nezdrave barve. (14: 107)

(4) malo filisterski izraz na polnih ustnih, zdrava barva na licih (7: 41) $\left(1^{\circ}\right)$ drhteći od studeni, bled i zelen, [... ] Davna je prevodio

$\left(2^{\circ}\right)$ zagrcava se $[\ldots]$ bled i pomalo zelen kao utopljenik $(5: 217)$

$\left(3^{\circ}\right)$ bled i zelen, sa zamršenom kosom i pomerenom kravatom (8: 260)

$\left(4^{\circ}\right)$ sa jakim podočnjacima i nezdravom bojom, on je ostavljao utisak nezdravog coveka (9: 76)

$\left(5^{\circ}\right)$ Zdrava boja koju su stekli na visini i na suncu [...]. (7: 248)

$\left(6^{\circ}\right)$ živo lice, sa zdravom bojom, finim crtama i modrim očim (2: 63)

1 - Troje povesti, 2 - Mimo življenja, 3 - Martin Kačur, 4 - Na večer, $1^{\circ}$ i $6^{\circ}$ - Travnička hronika, $2^{\circ}-$ Bife „Titanik“, $3^{\circ}-\check{S ̌ e t n j a, ~}^{\circ}-$ Knjiga, $5^{\circ}-\check{Z}$ eđ

Tabela 4: Primeri opisa boje lica

lica. Ako se detaljno opisuje izgled lika i njegovo lice, i pri tome navodi boja, do izražaja može da dođe „problem boje lica“ (Šolak 2003). Frekventnost reči „bled“ i „rumen“, može da postane znatna. Obično se poveća proporcija likova sa bledim licem. Ograničene su mogućnosti da se $\mathrm{i}$ izborom poređenja unese raznovrsnost. Rasprostranjena poređenja koja se oslanjaju na stalne etalone poprimaju formu fraze koja se ponavlja: bled kao platno / krpa / papir, bled kao mrtvac, žut kao limun / vosak, crn (mrk) kao ugljen / ugarak, crven kao rak / mak.

I Cankar i Andrić su nalazili mogućnosti da u opis lica pri pominjanju boje unesu ponešto raznovrsnosti i tako ublaže „problem boje lica“. U primerima 1 i $1^{\circ}-3^{\circ}$ (tabela 4) uz pominjanje zelene boje lica takođe je saopšteno da je osoba bila bleda. Takođe je navedena još poneka odlika koja se odnosi na spoljni izgled i ponašanje takve osobe: zatekle ruke, drhtanje, zagrcavanje, bez šešira, pomerena kravata. Opisujući lice, navodeći da je bledo, Dostojevski je u okviru jedne rečenice takođe pomenuo i zelenu boju. ${ }^{43}$ Izraz „zelen i bled“ upotrebio je i Svetolik Ranković u romanu „Seoska učiteljica“. ${ }^{44}$

Atributi „zdrav“ i „nezdrav“ u opisu lica u nekoliko navedenih primera u tabeli 4 udruživani su s drugim odlikama lica i opisom držanja tela. Cankar uz nezdravo lice na-

\footnotetext{
43 прокурор же показался мне [...] как-то бледным, почти с зеленым лицом (Достоевский 2012a: 889)

44 Gojko stajaše preneražen, zelen i bled, razrogačenih očiju od straha [...]. (Ranković 1952 knj. 1: 319)
} 
vodi da je sivo, sivkasto. Andrić pominje jake podočnjake. Pri navođenju izraza „zdrava boja lica“, „nezdrava boja lica“, pretpostavlja se da čitalac ima predstavu o takvom licu.

U tabeli 5 navedeni su primeri upotrebe atributa „bezbojan“ u Cankarevim i Andrićevim delima. Andrić je upotrebu atributa „bezbojan“ u svom delu ograničio na nekoliko javljanja. Cankar je uz atribut „bezbojan“ u primerima 7-9 u tabeli 5 udružio sa drugim osobinama „siv“, „sivkast“, „svelosiv“. U pitanju su osobine koje su pomenute i pri navođenju da je osoba nezdrave boje lica (primeri 2 i 3, tabela 4). Za bezbojne oči saopštava se još i da su polumrtve, mutne (primer 5 u tabeli 5). U Cankarevim opisima naslućujemo da je osoba s bezbojnim licem i bezbojnim očima lošeg zdravlja.

Ivan Cankar

(1) široka lica so bila brez barve. (10: 106)

(2) Poleg sebe je imel [...] študenta z zelo površnim in brezbarvnim obrazom, (7: 95)

(3) oči so bile motne, brezbarvne, polmrtve [...] In velike, brezbarvne oči so se obračale po udrtih globinah šiloma iz kota v kot [...]. (7: 100)

(4) oči gledajo neslano, brezbarvno, [...]. (7: 77)

(5) [...] obrazi so rdeli, oči so bile motne in brezbarvne.

(7: 183)

(6) mehk, brezbarvni, vodni človek, ki se mi je zdel nekak simbol neznačajnosti (6: 276)

(7) oči: [...] zmirom široko odprte, svetlosive, kakor brez barve (13: 178)

(8) Njen obraz je bil nekako brezbarven; $v$ senci je dobil skoro sivkasto polt. (8: 18)

(9) obraz je bil idealen; na vzbočenih, ostrih kosteh je bila napeta siva, brezbarvna koža (7: 60)

(10) brezbarvna koža se grba na kostéh, kakor ohlapna, mokra cunja. (7: 84)

(11) Gledal je z malimi vodenimi očmí brezbarvno, kot da bi ga vse to nič ne brigalo, (8: 210)

1 - Na klancu, 2 - Čudna povest, 3 - Brez prestanka, 4 - A jaz pojdem; 5 - Človek; 6 - Na izprehodu, 7 - Nina, 8 - Jesenske noči, 9 - Poglavlje o bradavici, 10 - Glad, 11 - Knjiga za lahkomiselne ljudi: Hudodelec, $1^{\circ}$ - Prozor, $2^{\circ}$ - Omerpaša Latas, $3^{\circ}$ - Anikina vremena, 4 - Žena na kamenu

Tabela 5: Upotreba atributa „bezbojan“ u opisu očiju, kože i lica $\left(1^{\circ}\right)$ debela, sa starinskim naočarima koje su se upijale u teško salo bezbojnog lica (9: 55)

$\left(2^{\circ}\right)$ Ta žena široka dobroćudna lica, sa plitkim spljošte-

$\left(3^{\circ}\right)$ Tane kujundžija, mršav, sa bezbojnim uvek raširenim očima u izmoždenom licu (7: 43)

$\left(4^{\circ}\right)$ majka, meka, bela, bezbojna žena sa pasivnom dobrotom ljudi koji su dobri $(7,212)$ nim nosićem i svetlim bezbojnim očima [...]. (15: 115) 
U proznim delima ruske klasične književnosti devetnaestog veka izrazi „bezbojne oči“ $i$ „bezbojno lice“ korišceni su u dužim rečenicama u kojima su se navodile i druge odlike fizičkog izgleda. ${ }^{45}$ (Bezbojno lice pomenuo je i Ljermontov u stihu ${ }^{46}$.) Atribut „bezbojan" u slikovitom opisu lica i očiju intenzivnije su koristili Cankarevi savremenici Andrejev ${ }^{47}$ i Kuprin. ${ }^{48}$

Gončarov nije pomenuo ni oči ni lice navodeći za jedan lik da je bezbojan. ${ }^{49}$ Pominjući jednog starca Kuprin saopštava da je bezbojan..$^{50}$ I Andrić je u primeru $4^{\circ}$ u tabeli 5 za jednu ženu rekao da je bezbojna, ne pominjući pri tome ni oči ni lice. Ostaje utisak da je to trajnija osobina lika. Čehov ${ }^{51}$ i Andrejev ${ }^{52}$ upotrebili su pridev „bezbojan“ u opisu grupe ljudi. Gorki je pri upotrebi prideva „bezbojan“ obično pominjao i neke druge odlike izgleda osobe, njenih očiju i lica. ${ }^{53}$ Pridev „bezbojan“ Gorki je navodio opisujući i

45 (1) И некрасив он был: худ, задумчив, черты неправильные, как будто все врознь, ни румянца, ни белизны на лице: оно было какое-то бесцветное. (2) на всю фигуру его, довольно худую, на худые руки, на выпуклый лоб и бесцветные щеки (3) глаза перестали искриться, а сделались прозрачны, бесцветны (Гончаров 2015: 112, 194, 353); (4) Лицо молодого человека было, впрочем, приятное, тонкое и сухое, но бесцветное, [...]. (5) Зосимов был [...] с одутловатым и бесцветно-бледным, гладковыбритым лицом, [...]. (Достоевский 1970: 4; 2012а: 176); (6) ничего не удавалось прочесть ей на этом бесцветном лице, кроме: пустой человек! (8) Это маленький, тщедушный человек, слабосильный и болезненный, с мелкими, бесцветными и крайне неопределенными чертами лица. (Чехов 1974 том 1: 409; 1976 том 5: 395)

46 Лицо бесцветное и взоры ледяные! (Лермонтов 1989 том 1: 155)

47 (1) с глазами бесцветными и спокойными (2) Король почти с отчаянием поднял на меня свои бесцветные глаза ры. (3) она прильнула к нему серым бесцветным глазом (Андреев 1971: 360,$373 ; 1995: 167)$

48 (1) Все в его глазах приобретало скучный и бесцветный вид, человеческие лица казались мутными, некрасивыми или болезненными, (2) Его старческие бесцветные глаза широко раскрылись с выражением безумного ужаса. (3) во всех этих лицах, во всех этих глазах, которые на минуту становятся бесцветными, бездонными и лживыми (4) с гневными, расширенными, выпуклыми, почти бесцветными от боли глазами) (5) денщик же таращил на него большие бесцветные глаза (6) Бесцветные светлые глаза глядели враждебно. (7) Глаза же у него были почти бесцветны [...]. (8) Он не спускает своих бесцветных, оловянных, но точных солдатских глаз с той единственной дорожки (9) был он вместе с бесцветным лицом с фигурой и костюмом (Куприн 1964 том 2: 7, том 3: 164, 271, том 4: 435, том 5: 101; том 7: 53, 1976: 70, 2013a: 334)

49 - Наташа была хорошенькая, но бесцветная, робкая натура. (Гончаров 2015: 502)

50 (1) Его жена какая-то бесцветная личность и совсем не представительна. (2) этот бесцветный старый Пьер (Куприн 1964 том 2: 50, том 7: 348)

51 Я не выношу постоянного покоя и бесцельной жизни, не выношу наших бесцветных и бледных людей, (Чехов 1999с: 87)

52 отовсюду тянулись к церкви бесцветные, как колокольный звон, молчаливые фигуры (Андреев 1995: 145)

53 (1) он просыпался, [...] смотревшей на неѐ и на всѐ пугливыми, бесцветными глазами. (2) Его добродушное лицо усеяно угрями, бесцветные глаза смотрели на всѐ с невозмутимым спокойствием. (3) Глаза у неѐ были бесцветные, неподвижные. (4) надзиратель, с длинным лицом, острой бородкой и бесцветными, неподвижными глазами (5) Пред Мишей мелькнуло худое, длинное лицо надзирателя, его круглые, бесцветные глаза, [...]. (6) Лицо [...] туповатое, робкие глаза бесцветны и выпучены, как у овцы. (7) некрасивое рябое лицо дворника, рассеянный взгляд бесцветных глаз (8) На его костлявом лице уныло торчал птичий нос, пугливо мигали круглые, бесцветные глаза, [...]. (9) полинявший человек с бесцветным и как будто стертым лицом (Горький 1950a: 168, 168, 257, 372, 373; 1950b: 20, 175; 1950с: 7; 1975 том 24: 570) 
nečiji govor, način na koji su u dijalogu izgovorene neke reči. U delima južnoslovenskih pisaca koja su poslužila kao izvor u ovom radu, korišcenje prideva „bezbojan“ u opisu likova nije rasprostranjena; nađeni su primeri upotrebe kod Vazova ${ }^{54}$ i Matoša. ${ }^{55}$

Birajući poređenja pri opisu izgleda lica i Cankar i Andrić su, pored drugih etalona, koristili i rasprostranjene. Uz imenicu „vosak“ u ulozi etalona poređenja navođene su različite osobine na kojima poređenje počiva. Upoređujući ga sa voskom Cankar je navodio da je lice bledo ${ }^{56}$, da je rumeno ${ }^{57}$, da je belo ${ }^{58}$. I Ćipiko je upotrebio imenicu „vosak“ kao etalon da bi istakao bledo lice..$^{59}$ Slično je postupio i Pelin. ${ }^{60}$ Pri upoređenju lica s voskom i drugi pisci su navodili da je ono bledo ${ }^{61}$, takođe i da je žuto, ${ }^{62}$ a ponekad i da je belo ${ }^{63}$. Andrić je poređenje sa voskom upotrebio u priči „Mila i Prelac“: „A utopljenik je kao vosak bled“ (Andrić 1978 knj. 9: 41). Komentar izraza „bled kakor vosek“ i „rumen kakor vosek“ naveo je Keberu svom rečniku (Keber 2011: 1052-3). U frazeološkom rečniku srpskog jezika navedeno je „žut (bled) kao vosak - vrlo bled (žut)“. (Otašević 2012: 116)

Kada je reč o slikovitom opisu izgleda lica i upotrebi rasprostranjenih poređenja u kojima se kao etalon javlja lice umrle osobe („bled kao mrtvac“, „bled kao smrt“) uočljivo je da su i Cankar i Andrić nastojali da unesu raznovrsnost i da izbegnu ponavljanje istovetnih izraza. Takve primere vidimo u tabeli 6 . Cankar je poredio lice neke osobe sa licem mrtvaca pri čemu su uključene i druge odlike, ne samo boja. ${ }^{64}$

54 Само малките му сиви безцветни очи играеха лукаво и злобно, като на маймуната. (Вазов 1956 том 12: 16)

55 gledao je bezbojnu put što se bjelasa kraj tamne kose (Matoš 1953: 150)

56 (1) Perin obraz je bil bled, kakor vosek in obrvi so se mu tresle. (2) [...] bled je bil njen obraz, trd i mrzel, kakor od voska. (Cankar $1969 \mathrm{knj} .7$ : 172; $1970 \mathrm{knj} .12$ : 335)

57 Njegov obraz je bil v mesečini rumen kakor od voska. (Cankar 1973 knj. 13: 114)

58 Zablisnilo se je in tedaj se je zasvetil obraz, bel kakor od voska. (Cankar 1971 knj. 10: 202)

59 (1) Jerica je molčala zdaj kakor mrlič; bleda kakor vosek je zrla na medene gumbe svojega sedla (Levstik 1913: 465) (2) kao da je bez krvi; lice nabuhnulo, blijedo kao vosak (Ćipiko $1951 \mathrm{knj} .1: 93$ )

60 бледо като восък лице бе изписана ужасна мъка (Пелин 1977 knj. 1: 293)

61 Лицо стало такое длинное да бледное, как воск, а черные волосы еще более увеличивали эту бледность. (Лесков 1973 том 1: 125)

62 (1) Покойница лежала на столе, желтая как воск, [...]. (Пушкин 2016: 133); (2) Mršava kao svijeća, žuta kao vosak, [...]. (Šenoa $1983 \mathrm{knj.} \mathrm{1:} \mathrm{27);} \mathrm{(3)} \mathrm{[...]} \mathrm{lice} \mathrm{Podgorskoga.} \mathrm{Bilo} \mathrm{je} \mathrm{ono} \mathrm{žuto} \mathrm{poput}$ voska, [...]. (Kovačić, А. 1950: 175); (4) Лицето беше жълто като восък. (Вазов 1956 knj. 8: 91);(5) Lica joj požutjela kao vosak (Matavulj 2007 3: 69)

63 Njezino poput voska bijelo i oslabljeno lice [...]. (Novak 1951: 225)

64 (1) Žalostni so bili obrazi v njeni luči, kakor obrazi mrtvecev. (2) Obraz je bil siv in košcen, kakor obraz mrtveca. (Cankar knj. 13: 27; knj. 17: 225) 
Ivo Andrić

(1) Tudi na njegov obraz so sijale in je bil tako bel kakor mrtvecev obraz. (13: 63)

(2) ko drugi vsi že zdavnaj spe,tihi in bledi, brez diha, mrtvecem podobni. (23: 55)

(3) Roke [...] koščene kakor roke mrtveca in belota njenih lic je bila mrtvaška belota. (13: 74)

(4) Ali to ni bila voščena, mrtvaška bledota. (7: 90)

(5) bled obraz, mrtvaški lobanji podoben. (19: 132)

(6) sklenila je roke [...] premočena in blatna do pasú, v lica bleda in upala kakor mrtvec (14: 175)

(7) opazovala [...] kako se razliva polagoma čez moje čelo svetla mrtvaška bledota (9: 255)

(8) V čelo in v senca je zardel, lica pa so bila tako zamolklo bleda, kakor lica umirajočega. (17: 99)

(9) Njegov obraz je bil tako bled [...] kakor mrliški. (8: 75)

1 i 3 - Potepuh Marko i kralj Matjaž, 2 - Podobe iz sanj, 4 - Čudna povest, 5 - Troje povesti: Krčmar Elija, 6 - Smrt in pogreb Jakoba Nesreče, 7 - Smrt kontrolorja Stepnika, 8 - Novo življenje, 9 - Popótovanje Nikolaja Nikiča;,1 ${ }^{\circ}$ - Na Drini ćuprija, $2^{\circ}$ i $3^{\circ}$ - Travnička hronika, $4^{\circ}-$ Anikina vremena, $5^{\circ}-Z$ mija, $6^{\circ}-$ Izlet, $7^{\circ}-$ Omerpaša Latas, $8^{\circ}-$ Zeko $\left(1^{\circ}\right)$ Ćuti i Nailbeg, [...] i bled kao mrtvac pretura neku odluku u glavi. (1: 358)

$\left(2^{\circ}\right)$ Davna je bio bled kao pokojnik, sa kapljama hladnog znoja na čelu. (2: 244)

$\left(3^{\circ}\right)$ Bio je samrtnički bled. (2: 180)

$\left(4^{\circ}\right)[\ldots]$ dobrunski proto leži kod kuće bled i nepomičan kao mrtvac. (7: 71)

$\left(5^{\circ}\right)$ onda se bolesnica umiri, mrtvački bleda, sa kratkim dahom (9: 114)

$\left(6^{\circ}\right)$ lice joj se dobro ne razaznaje, samo se vidi da je mrtvački bledo od besa (9: 155)

$\left(7^{\circ}\right)$ on je s vremena na vreme odizao pogled, posmatrao [...] samrtnički bledo begovo lice (16: 70)

$\left(8^{\circ}\right)$ Bilo je žena koje su ležale sa mrtvački bledim licima i mokrom krpom na čelu.(5: 322)

Tabela 6: Upotreba atributa „bezbojan“ u opisu očiju, kože i lica

Uproznim delima ruske književnosti devetnaestog veka pri slikovitom opisu bledog lica rasprostranjeno je upoređenje sa licem umrle osobe. Česta je upotreba poređenja бледный как мертвеи, бледный, как смерть. Takva poređenja upotrebili su na 
više mesta u svojim delima Gogoljj $j^{65}$, Dostojevski ${ }^{66}$, Čehov ${ }^{67}$. Slične primere nalazimo i u delima drugih ruskih pisaca: Ljermontova ${ }^{68}$, Turgenjeva ${ }^{69}$, Leskova ${ }^{70}$, Kuprina ${ }^{71}$, Pasternaka $^{72}$, Bulgakova ${ }^{73}$. Đura Jakšicic ${ }^{74}$ i Simo Matavulj ${ }^{75}$ pri opisu lica bili su skloni

65 (1) На пне показался сидящим Басаврюк, весь синий, как мертвец. (2) помещица Коробочка, перепуганная и бледная как смерть, и рассказывает (3) Приятная дама, услышав это, так и окаменела на месте, побледнела, побледнела, как смерть и, точно, перетревожилась не на шутку. (4) она статуя и бледна как смерть. (5) Машка моя видит, что я бледна как смерть. (6) вы бледны как смерть (Гоголь 2009с: 64; 2009а: 260, 263, 264, 267, 267)

66 (1) Когда мы вошли в комнату, с ним сделалось дурно; он был бледен, как мертвый. (2) - Гаврила, подбери его! - вскричал дядя, бледный как мертвец (3) Настя побледнела, как мертвая, и робко проговорила; (4) заключил он, побледнев как мертвый. (5) Степан Трофимович, весь бледный как смерть. (6) бледный как мертвец, зловещим взглядом посмотрел на смеющуюся. (7) он только вас пугает; побледнел как мертвец! (Достоевский 1988a: 126, 169, 182; 1998: 217; 2012b: 350, 498, 663

67 (1) Леля, трепещущая, бледная как смерть, ошалевшая, сделала шаг вперед, покачнулась. (2) Бледный, как смерть, дрожащий, он выполз наполовину из окна [...]. (3) бежать подальше с этой бледной, как смерть, забитой, горячо любимой женщиной (4) - За что он eе? - спрашивали они, бледные, как смерть. (5) Ты бледна, как мертвец, и дрожишь! (6) как мертвенно-бледна была она, когда поздно вечером выходила (7) Грохольский прислушался и, побледнев, как смерть, тихо зашагал к беседовавшим. (8) Зинаида Федоровна, бледная, как мертвец, стояла среди комнаты (9) Несмотря на то, что он был болен и бледен, как мертвец (Чехов 1999d: 223, 255, 272, 274, 284, 356; 1977 том 8: 194 том 9: 216; 1974 том 1: 6)

68 (1) - Согласен, - прошептал Азамат, бледный как смерть. (2) они были бледны как смерть (Лермонтов 1977: 36, 157)

69 (1) Вы бледны как мертвец, вы больны. (2) Яков открыл свое лицо - оно было бледно, как у мертвого [...]. (Тургенев 1981: 344; 2013: 239)

70 (1) Настя надела поданное ей колечко, а сама бледная как смерть; (2) Стала Настя биться у них в руках, побледнела как смерть и кричи (3) влетает в избу Якова Яковлевича жена, вся бледная как смерть, и говорит (Лесков 1973 том 1: 127, 166; том 2: 382)

71 (1) - Вы бледны, как смерть, Лидия Николаевна, не хотите ли воды? (2) Сидевшая перед ним бледная, как смерть, девушка [...]. (Куприн 1964 том 1: 48, 110)

72 Вдруг в дверь заглянул бледный, как смерть, Ерофей [...]. (Пастернак 2011: 301)

73 Приезжает бледная как смерть и рассказывает. (Булгаков 1993: 212)

74 (1) crte u sviju puna bola, a lica bleda kao smrt (2) U tome dovedoše Milisava, vezana, a u licu beše bled kao mrtvac i uzvereno gledaše u skupljenu gomilu. (3) bled kao mrtvac, a glava mu klonula na grudi (4) sasvim sama: kao mrtvac koga srodnici i prijatelji ostave u groblju (5) Popa Tihomir preblede kao smrt, [...]. (6) Vrata se otvoriše i, bleda kao smrt, iziđe Ružica. (7) Obrazi mu dođoše bledi kao u mrtvaca (8) bolesnica stade bleda kao smrt (Jakšić 1978 knj 2: 7; knj 3: 161, 165; knj. 4: 164; 1950: 28, 161, 359, 417)

75 (1) [...] otprilike kao mrtvacu koji se zadovoljan sa svijetom rastao. (2) lice mu ublijedilo, kao samrtniku (3) Marko Pivić, blijed kao mrtvac, prope se navrh prsta (4) bjesmo blijedi kao mrtvaci. (5) Bila je blijeda kao smrt. (6) leđima prislonjena uza zid, blijeda kao smrt (7) zovnu momka, koji lagano otvori, blijed kao smrt (8) sva lica vijećnika, koja su dotle izgledala kao mrtvačka, sinuše (9) Brkić, blijed kao smrt, nasloni se na suhomeđu (10) nazrijeh [...] koja problijedi kao smrt! (Matavulj 2006 knj. 1: 110, 316; knj. 2: $110,77,85,254,271,283,440,449)$ 
poređenju s licem umrle osobe. Primere takvih oređenja nalazimo i u delima drugih južnoslovenskih pisaca, u bugarskoj ${ }^{76}$, srpskoj $^{77}$, hrvatskoj $^{78}$ i slovenačkoj književnosti. ${ }^{79}$

\section{Osvrt na upotrebu nekoliko odabranih izraza}

Izrazi navedeni u primerima u naredne tri tabele ne javljaju se često ni u Cankarevom ni u Andrićevom delu. Imali smo u vidu izraze za koje je nađeno nekoliko upotreba kako kod jednog, tako i kod drugog pisca.

\subsection{Osvetljen iznutra}

Primeri u tabeli 6 sadrže moćno poređenje u opisu lica i drugih objekata. Ono što se opisuje izgleda „kao da je osvetljeno iznutra“.

U primerima iz Cankarevog dela u levoj koloni tabele 7 opisano je ljudsko lice. ${ }^{80}$ Odabrano poređenje odražava lepotu lica. ${ }^{81}$ U prevedenom tekstu koji je naveden ispod tabele 7 vidimo da je upotrebljen glagol „ozariti“ koji se ne javlja u navedenim primerima iz Andrićevog dela.

76 (1) изправи се побледнял като мъртвец (2) Жените, неми, като смърт бледни, без да им поръчват, извадиха каквото имаха ценно (Вазов 1956 том 12: 19, том 13: 31); (3) Когато подигна лицето си, то беше желто и обтегнато като на мъртвец; (4) лицето му, слабо и желто като на мъртвец (5) Токмакчията се обърна [...] изпит и бледен като мъртвец (6) И при слабия блясък на кандилата лицата им изглеждаха бледи и измъчени като на мъртъвци (Йовков 1982 knj. 1: 164, 228; 1983 knj. 2: 106, 263); (7) образите по иконите са побледнели като мъртъвци. (8) Той се крепеше на ръцете им, бледен като мъртвец, съкрушен, (Пелин 1977 том 3: 39, 79)

77 (1) Krunija izida iz sobe, bleda kao mrtvac. (Veselinović 1983: 168); (2) [...] razrogačio oči, a prebledeo kao mrtvac. (Domanović1974: 19); (3) I tada se opet ugledah u ogledalu, ali tako mrtvački bled, bled kao duh, nikad nisam bio. (Vasić 1990b: 53) (4) trepavice mirno leže na blijedome licu, kao u mrca, (Ćipiko 1951 knj. 3: 234); (5) Jadna Tuba poblijedi kao mrtvac, ali se uzdrža. (6) Za trenut oka sklopiše se soldati oko nji, a oni preblijediše ko mrtvaci. (Kočić 2002: knj. 1: 139, 150)

78 (1) robijala se onako niska i okrupna kroz razjarenu svjetinu, blijedožuta kao mrtvac, (Novak 1965: 118); (2) Stajaše uza zid prislonjen i blijed kao mrtvac, raskuštrane sijede kose i krvavih očiju. (Šimunović 1952 knj. 1: 291); (3) Crnomanjasto mu lice bješe problijedjelo, kao da je mrtvac. (4) dahne prestrašeno Irena i klone na stolicu blijeda kao smrt. (5) Jakov blijed kao smrt, pođe iz plesaonice. (6) Blijed kao mrtvac. (Kumičić 1950 knj. 1: 86, 393, 404; 1985: 168); (7) Bijaše blijed kao mrtvac, a iz rane tecijaše mu obilna krv (Tomić 1970: 90) (8) Lice dugoljasto, žalovito i blijedo kao u mrtvaca. (8) Mlinarić sune u kuću, vrati se odjeven i stane se praštati blijed kao mrtvac. (Matoš 1953 knj. 1: 228; 1973: 214); (9) opazio sam da sam blijed kao smrt (Donadini 1968: 158)

79 (1) prične tipati po Tonetu, ki je naenkrat bled kakor mrlič (Pugelj 1948: 121); (2) bila je bleda kakor smrt, in njena drobna desnica je stiskala krčevito majhen samokres. (3) In njen obraz, ki se je bil zadnje čase čudno izpremenil, je postal mrtvaško bled. (Levstik 1966: 281)

80 (1) Na mizi je stala svetilka in je sijala na obraze, da so bili lepi in svetli, kakor obžarjeni od nebeske luči. (2) Rdeč solnčnik je senčil obraz [...] kakor da bi sijal skozi prozorno kožo plamen iz krvi, iz mesa. (Cankar 1967 knj. 6: 247; 1972 knj. 11: 213)

81 Objašnjenje izraza biti ožarjen od notranje luči: „nenavadno, izredno lep: doživljati čudežno ljubezen (pesn.)“, Slovar slovenskega knjižnega jezika, Inštitut za slovenski jezik, SAZU, http://bos.zrc-sazu.si/cgi. 
(1) Njen obraz je bil tako bel, da se je svetil v mraku, kakor od čudežne notranje luči obžarjen. (23: 114)

(2) [...] zasijejo svetilke kakor sonca in vsi obrazi žaré kakor od notranje luči. (12: 69)

(3) obraz sladak in svetal, takorekoč od notranjega ognja obžarjen. (24: 265)

(4) videla je bel, [...] od notranjega plamena razpaljen obraz (20: 206)

(5) njegov obraz je bil svetel, kakor žarka bela luč je sijala iz njega (16: 231) $\left(1^{\circ}\right)$ njene oči, inače zagasite, bile su sada, kao osvetljene iznutra (7: 40)

$\left(2^{\circ}\right)$ Aska, čista [...] sivkasta kad bi ušla u pramen tanke magle, a svetla, kao iznutra obasjana, kad bi se našla na čistini prelivenoj suncem. (9: 191)

$\left(3^{\circ}\right)$ To su bile [...] oči, koje je ona osvetljavala i gasila iznutra; (10: 177)

$\left(4^{\circ}\right)$ Ispija naglo, a vino ga munjevito odmah obasja iznutra. (8: 58)

$\left(5^{\circ}\right)$ Žućkasti porozni kamen od kojeg je most sagrađen [...] sijao je u mraku kao osvetljen iznutra. (1: 85)

$\left(6^{\circ}\right)$ [te oči] liče na deo globa koji, prigušeno osvetljen iznutra, nagoveštava [...] delove kontinenata (7: 256)

Prevedeno: (1) Njeno lice je bilo tako belo da se svetlelo u mraku, kao čudesnom unutrašnjom vatrom ozareno. (2) [...] svetiljkje zasjaju kao sunca i sva lica zrače, kao od unutarnje svetlosti; (3) [...] lice slatko i svetlo, tako reći od unutrašnje vatre ozareno. (Cankar 1956: 157; 2006: 80; 1981: 64)

1 - Podobe iz sanj, 2 - Gospa Judit, 3 - Bela hrizantena, 4 - Milan i Milena, 5 - V samoti, $1^{\circ}$ - Anikina vremena, $2^{\circ}-$ Aska i vuk, $3^{\circ}-$ Lica, $4^{\circ}-$ Svečanost, $5^{\circ}-\mathrm{Na}$ Drini ćuprija, $6^{\circ}-$ Jelena, žena koje nema

Tabela 7: Upotreba izraza „osvetljen iznutra“

Izraz „osvetljen iznutra“ u primerima $1^{\circ}-4^{\circ}$ Andrić je upotrebio pri opisu ljudskih očiju, zatim pri opisu ovčice Aske, te mosta na Drini. U opisu lica Mehmedpaše Biogradlije u priči „Kod kazana“ Andrić je pomenuo sjaj „koji dolazi iznutra“ (Andrić 1978 knj. 6: 59). I u Cankarevom delu nalazimo neke primere u kojima je istaknut sjaj na licu $^{82}$. Lice obasjano unutarnjom svetlošću opisao je i Vjenceslav Novak u romanu „Poslednji Stipančići“"83. Na sličan način opisali su lice, Vazov u romanu „Pod igom” ${ }^{\text {" }}$, i Gorki, u romanu „Mati”85.

82 (1) Ves klanec je bil v senci, samo njen obraz se je svetil tako čudno, kakor da bi bila luč v njem in ne na oni strani, na večernem nebu. (2) beli obrazi, tako svetli, kakor da jim je gorelo pod kožo; (3) bela, ozka lica so prežeta s svetlobo in toploto, kakor da gori v njenem srcu tiha luč. (4) kakor da bi luč ne sijala nanjo od nebes, temveč od samih njenih lic (5) ves miren je, kakor obžarjen od božjega plamena, ki gori globoko v duše dnu“ (Cankar 1975 knj. 16: 208; knj. 19: 195; knj. 22: 35, 37; knj. 23: 73)

83 Njegovo se strogo i hladno lice razvedrilo kao naglo obasjano nutarnjim svijetlom [...]. (Novak 1957: 174)

84 Вътрешна радост озари лицето му. (Вазов 1956: 36); U beogradskom izdanju romana prevedeno je: „Neko unutrašnje zadovoljstvo ozari njegovo lice.“ (Vazov 1975: 40)

85 Это краткое слово как будто осветило ее изнутри и сделало ясным все извне. (Горький 1970 том 8: 262) 


\section{2 „Sa obe ruke“}

Muškarac koji sa obe ruke skida s glave šešir, kapu, šubaru ili fes, može da odaje osobu u posebnom psihološkom stanju.Takav detalj u opisu ponašanja mladog kočijaša koji žali za umrlom ženom, i koji mnogo pati, naveo je Turgenjev u kratkoj prozi „Maša“. ${ }^{86}$ Sličan detalj nalazimo i unjegovim drugim delima. ${ }^{87}$ I Zbašnik je naveo slično saopštenje. ${ }^{88}$

$\mathrm{U}$ primeru $2^{\circ} \mathrm{u}$ tabeli 8 Andrić je opisujući gazda-Jevrema koji sa obe ruke skida fes sa glave, dopunski u nastavku teksta, rečenicom u zagradi obrazložio tu ranju: „To se dešavalo samo u trenucima velikog uzbuđenja i bezizlaznosti, koji su kod gazda-Jevrema bili veoma retki." $U$ drugim primerima u tabeli 8 u pitanju je stanje u kom se nalazi jedna osoba opterećena nelagodnošću prilikom obraćanja drugoj osobi, dok sa njom komunicira, ili jednostavno, dok se boravi u njenoj blizini.

Ivan Cankar

Ivo Andrić

(1) Nato je vstal, pa odkril se je in je držal klobuk z obema rokama. (16: 8)

(2) Lenart je stal troje korakov pred njim, držal je klobuk z obema rokama, ter poslušal. (22: 104)

(3) Klobuk je držal z obema rokama na hrbt, [...]. (11: 22)

(4) priklonil se je bil globoko, klobuk je držal z obema rokama, kolena so se mu tresla (13: 91)

(5) Očitno je bilo, da ni odgovarjal rad; gledal je v tla, $\mathbf{z}$ obema rokama je držal klobuk; (16: 130)

(6) z obema rukama je držal tisti okrogli preprosti klobuk s črnim trakom (17: 349)

(7) črni klobuki, potisnjeni na glavo $\mathbf{z}$ obema rukama (15: 89)

1 - Hlapec Jernej in njegova pravica, 2 - Grešnik Lenart, 3 - Hiša Marije Pomoćnice, 4 - Potepuh Marko in kralj Matjaž, 5 - Polikrap, 6 - Poet Peter, 7 - Nespodobna ljubezen; $1^{\circ}$ - Nemirna godina, $2^{\circ}$ - Cirkus, $3^{\circ}-$ Žena na kamenu $\left(1^{\circ}\right)$ Pred sobom je nosio sa obe ruke svoj veliki crni šešir kao neki predmet koji je ranije zaboravio ovde i sad odlazizadovoljan što ga je našao. (15: 71)

$\left(2^{\circ}\right)$ A kad je ostao sam, skinuo je sa obe ruke teškim pokretom fes sa glavei stavio ga pored sebe glave, pažljivo kao da je od stakla. (5: 113)

$\left(3^{\circ}\right)$ Sa obe ruke držao je kapu na grudima nepomičan u svom neprirodnom položaju [...]. (7: 209)

Tabela 8: Postupanje sa šeširom, kapom, fesom i upotreba izraza „sa obe ruke“

\footnotetext{
86 он начинает кланяться [...] прижимая обеими руками шляпу к желудку“ (Тургенев 1982 том 10: 136)

87 (1) подошел, поклонился низехонько, взяв шляпу в обе руки, и сказал (2) Он поклонился мне низехонько, взявшись обеими руками за шапку [...]. (Тургенев 1982 том 10: 18, 136). Prevedeno: (1) priđe, duboko se pokloni, uze šešir obema rukama, i reče (2) On mi se nisko pokloni, uzevši se obema rukama za kapu [...]. (Turgenjev 1977: 365).

${ }^{88}$ Mihec je držal z obema rokama klobuk za široke kraje, [...]. (Zbašnik 1893: 47)
} 
$\mathrm{Na} \mathrm{kraju} \mathrm{priče} \mathrm{„Cirkus“} \mathrm{Andrić} \mathrm{je} \mathrm{upotrebio} \mathrm{poređenje} \mathrm{dok} \mathrm{opisuje} \mathrm{junaka} \mathrm{priče,} \mathrm{di-}$ rektora cirkusa Ronalda koji odlazi noseći šešir sa obe ruke (primer $1^{\circ}$, tabela 8). U završnom delu priče opisani su direktorovi pokušaji da objasni sudijama posebne okolnosti pod kojim je počinio zločin. Ali, niko od sudija nije pokušavao da ga razume, pa ni da dokraja sasluša optuženog direktora. Andrićev Ronaldo u nečem podseća na Cankarevog Jerneja. Slična je nesaglasnost Jernejevih i Ronaldovih pogleda na pravičnost i suđenje, na odnos između onoga ko traži pravdu i samih sudija. Jerneju ne uspeva da „sa ljudima od vlasti“ dijalogom uspostavi „razumevanje za svoje viđenje sveta“ (Vučenov 1977: 195). To ne uspeva ni Andrićev Ronaldo.

\section{3 „Iz jednog komada“}

Navođenje da je nešto „iz jednog komada“ može da upućuje na ujednačenost, kompaktnost, kontinuitet, kao u primerima 1-3 u tabeli 9. Opisujući izgled hana sagrađenog pored mosta na Drini Andrić je u romanu „Na Drini ćuprija“ ponovio saopštenje da su rešetke na prozorima sečene iz jednog komada kamena (primeri $1^{\circ}$ i $2^{\circ}$ ). Tako je uz pomenutu monumentalnost građevine istakao i njenu lepotu. Izraz je još jednom ponovio opisujući zle namere onih koji ruše (primer $3^{\circ}$ ). Vidimo da su u primerima iz tabele 12 izrazi „kao da je iz jednog komada“, „kakor iz enega kosa“, upotrebljen i u slikovitom opisu posve različitih objekata.

Ivo Andrić

(1) tisti krasni primitivni časi, ko so bili nazori in čuti kakor rezani iz jednega kosa (7: 125)

(2) suha ženska, zavita v haljo, ki je bila šita kakor iz enega kosa in je segala od vratu do nog. (19: 54)

(3) Obrazi so si bili čudno podobni, kakor iz enega kamna izklesani; iz trdega kamna [...]. (22: 99) $\left(1^{\circ}\right)$ rešetke, ali ne od gvožđa, nego klesane u sedri i svaka iz jednog komada (1: 79)

$\left(2^{\circ}\right)$ veliki prozori u prizemlju, svedeni na luk, sa rešetkama koje su [...] sečene u mekom kamenu, iz jednog komada (1: 84)

$\left(3^{\circ}\right)$ porazbijaše one neobično fine rešetke na prozorima, sečene iz jednog komada (1: 144)

$\left(4^{\circ}\right)$ Kad je ona, pre trideset godina, došla u Bosnu i otpočela rad, život je izgledao kao da je iz jednog komada. (1: 323)

$\left(5^{\circ}\right)$ Njen osećajni svet bio je tada još netaknut, sliven sav iz jednog komada i teško pristupan [...]. (7: 213)

1 - Literarno izobraženi ljudje, 2 - Troje povesti, 3 - Grešnik Lenart; $1^{\circ}, 2^{\circ}, 3^{\circ}$ i $4^{\circ}-\mathrm{Na}$ Drini ćuprija, $5^{\circ}$ - Žena na kamenu

Tabela 9: Upotreba izraza: „iz jednog komada“ 


\subsection{Sahrana i grob}

Razgovor u raznim prilikama može da bude upoređen s razgovorom pored odra u blizini mrtvaca (primeri 1 i $1^{\circ}$, tabela 10$)^{89}$. Ponašanje ljudi oko odra, prilikom sahrane i neposredno posle nje, ima tipičan odraz na način vođenja razgovora, na pokrete i hod.

Ivan Cankar

Ivo Andrić

(1) Govoril sem šepetajoč, kakor ob mrtvaškem odru

[...] (14: 158)

(2) $[\ldots]$ šepetale so si od ušesa do ušesa, kakor se spodobi v bližini mrličevi [...] (18: 182)

(3) Govorili so šepetaje, kakor na pogrebščini. (20: 165)

$\left(1^{\circ}\right)$ Razgovor, tako reći, kraj mrtvaca. (8: 65)

(4) Kakor v grobu je bilo tam - tiho, zadehlo, [...]. (10: 31)

(5) Tako samotno je tukaj, kakor v grobnici. (13: 87)

$\left(2^{\circ}\right)[\ldots]$ razgovarao je s ljudima, ali onako usiljeno $i$ neobično kao što se razgovara posle sahrane. (7: 69)

$\left(3^{\circ}\right)$ U velikoj sobi, u kojoj je bilo tiho kao u grobnici, [...]. (5: 55)

$\left(4^{\circ}\right)$ Vraćali su se kao sa zvaničnog pogreba. (2: 452)

$\left(5^{\circ}\right)$ Same se noge saviše [...] i bez misli i reci on leže u mrak i nečistoću kao u svoj rođeni grob. (1981: knj. 14: 223)

(6) tako jim je bilo pri srcu, da bi se odkrili in pokrižali, kakor ob pogrebu. (19: 111)

$\left(6^{\circ}\right)$ u moje vidno polje ulazi i list sam, i brzo poklapa svoju senku, leže u nju kao u svoj grob (14: 377)

(7) Iz srca Aleševega je izginila vsa radost, [...] kakor da je bil prišel naravnost od pogreba. (14: 255)

(8) vtisti osamljeni izbi, ki je nema, tiha in mrzla kakor grob (19: 212)

1 - Smrt in pogreb Jakoba Nesreče, 2 - Gospod Vavra; 3 - Milan i Milena, 4 - Na klancu, 5 - Potepuh Marko i kralj Matjaž, 6 - Krčmar Elija, 7 - Aleš iz razora, 8 - Hoja v šolo ; $1^{\circ}-$ Reči, $2^{\circ}$ - Anikina vremena, $3^{\circ}$ - Priča o vezirovom slonu $4^{\circ}$ - Travnickka hronika, $5^{\circ}-$ Smrt Stevana Karajana, $6^{\circ}-$ Znakovi pored puta

Tabela 10: Imenice „mrtvac“, „sahrana“, „grob“ kao etaloni poređenja

Tišinu kao odliku neke situacije Cankar i Andrić slikovito su opisali upotrebom izraza „kao u grobu“. Slične izraze „tiho kao u grobu“, „mirno kao na groblju“ (primeri 4 i $3^{\circ}$, tabela 10) nalazimo kod Ljermontova ${ }^{90}$, Gončarova ${ }^{91}$, Čehova ${ }^{92}$, Gorkog ${ }^{93}$. Vraćanje s

89 U nekim slučajevima bi se moglo reći da se razgovara „kao da tu nije mrtvaca“: Ali stari smiono zametne razgovor, kao da nije tu mrca, pa i ostali slobodnije odahnuše. (Ćipiko 1951 knj. 2: 210)

90 там внизу казалось темно и холодно, как в гробе (Лермонтов 1977: 141)

91 (1) Ее всегда увидишь, что она или возникает, как из могилы, из погреба, с кринкой, горшком, (2) Перед ней - только одна глубокая, как могила, пропасть. (3) Но в кабинете Обломова всѐ было тихо, как в могиле. (Гончаров 2015: 639; 2012: 105)

92 была тишина мертвая, какая подобает кладбищу (Чехов 1977 том 9: 226)

93 Тихо, как в могиле, даже мышей нет, и такая тьма, что руки тонут в ней: [...]. (Горький 1950: 283) 
pogreba praćeno je i posebnim psihološkim stanjem. Upoređenje sa takvim stanjem u primerima $5^{\circ}$ i 6 slikovito je opisano stanje potištenosti. Cankar je imenicu „grob“ u opisu izgleda osobe upotrebljavao i u hipotetičnim poređenjima. ${ }^{94}$

Izdvajanje iz sredine, odlazak i povlačenje na neko mesto Andrić je u uporedio s polaganjem u grob (primeri $5^{\circ}$ i $6^{\circ}$, tabela 10 ). Imenica „grob“ javlja se uz glagol „leći“: leći kao u grob. Poređenjem u primeru $5^{\circ}$ završena je priča „Smrt Stevana Karajana“. Ono odražava psihološko stanje glavnog lika koji ne može da se pomiri s onim što ga je snašlo. Turgenjev je upotrebio slično poređenje. ${ }^{95}$

Imenicu "grob“ kao etalon poređenja upotrebili su Georgiev ${ }^{96}$ i Humo. ${ }^{97} \mathrm{U}$ opisu tame i pomrčine upotrebljen je izraz „kao u grobu“.98 Izraz „kao u grobnici“ upotrebili su Tomić ${ }^{99}$ i Veselinovićc ${ }^{100}$. Slična poređenja nalazimo u delima srpskih ${ }^{101}$ i hrvatskih pisaca. ${ }^{102}$ Opisane su razne situacije upotrebom poređenja u kojim se uz etalon „grob“ koriste i pridevi: „pust“ „tih“, „taman“, „Zagušljiv“, „crn“, „prazan“. U primerima $3^{\circ} \mathrm{i}$ $7 \mathrm{u}$ tabeli 10 sa grobom je upoređeno stanje u prostoriji. Cankar je i na drugim mestima upotrebio imenicu „grob“ u opisu stanja i izgleda nekog mesta. ${ }^{103}$ Slično su postupili i

94 (1) Bilo mi je, kakor da bi bil vstal iz groba. (2) In zdaj kar nenadoma, kakor da bi se opolnoči duh vzdignil iz groba. (3) In ko je vzdignil glavo, so bila njegova lica bleda, kakor da je bil vstal iz groba. (4) Gledal je z izbuljenimi, prestrašenimi očmi, kakor da bi bil vstal iz groba. (5) Sredi izbe je plesal upognjen starec, tako suh, siv, krivenčast in betežen, kakor da je bil ob belem dnevu iz groba vstal. (6) drugačen - kakor da se je bil vzdignil iz groba. (7) Strmeli so vsi na osojniškega, biriča, ki je stal pred njimi ves preplašen, kakor prikazen iz grobov. (8) Kakor da sem bila iz groba vstala, tako se mi čudiš! (9) Komaj razumljivo, zamolklo, plaho mrmranje, kakor iz grobov; (10) Senca je izginila tiho, kakor je bila vstala iz groba. (Cankar 1976: knj. 9: 260; knj. 14: 141, 267, knj. 18: 22, 65, 193; knj. 19: 188; knj. 22: 242; knj. 23: 81, 82)

95 Я поклонился моей улетевшей жизни - и лег в постель, как в могилу. (Тургенев 1982 том 10: 183)

96 Па и... празна.... като гроб! (Георгиев 1980: 310)

97 Tiho je kao u grobu. (Humo 1955: 196)

98 (1) Svud tamno, kao u grobu. (Kumičić 1950 knj. 1: 128); (2) našao se poklopljen crnom tminom kao u grobu. (Novak 1951: 438); (3) noć pada na Hrvatsku, noć crna kao grob (Matoš 1953 knj. 1: 215)

99 nastala u Bosni tišina kao u grobnici (Tomić 1970: 58)

${ }^{100}$ Zavlada tišina kao u grobnici. (Veselinović 19??: 400)

101 (1) I tu je bilo sve mirno kao u groblju, samo poneki pas što reži (Jakšić 1978 knj. 3: 240); (2) I samo to, sve drugo beše mirno kao u grobu (3) Nasta tajac. Tišina kao u grobu. (4) Zavlada tajac, kao u grobu. (5) Zaćutaše. Tajac je bio kao u grobu. (6) U šatoru beše tišina kao u grobu. (Veselinović 1983: 315, 343, 342, 400); (7) Sve je tiho kao u groblju. (Lazarević 2011: 150) (7) Sad opet nasta mir, kao u grobu, [...]. (Matavulj 2006 knj. 1: 326); (8) I ja sam, odista, tako osećala kao da sam u grobu. (Jakšsić 1978 knj. 4: 183); (9) ona zajauka, ama onako ženski, kao na groblju. (Sremac 2011b: 312); (10) po pustim ulicama, njegovi koraci odjekivali bi kao u velikoj grobnici (Ćipiko $1951 \mathrm{knj} .3: 228$ )

102 (1) Već se je spuštala noć; tiho kao u grobu, [...]. (2) Tiho je kao u grobu. (Šenoa 1983 knj. 1: 102, 229); (3) Bjaše mirno kao u grobu (Šenoa 1983: knj. 2: 202); (4) U kući je sve tiho, kao u grobu. (Kumičić 1885: 285); (5) Tiho ko u grobu. (Matoš 1953: 243); (6) Nijemo kao u grobu, ni lahorka da trepne. (Matoš (1953 knj. 1: 269); (7) po kući radi i Palunka dvori, a kuća tiha i pusta kao grob. (Brlić-Mažuranić 1926: 56); (8) mora da se osjeća u njima duboka tišina kao u grobu (Donadini 1968: 158); (9) [...] urlikao vjetar i mrak zatvarao prostor kao u grobu. (Kovačić 1983: 150)

103 (2) [...] morda se je zdelo Francki tako samotno in tiho, ker je bila hiša pusta, kakor velik grob (4) Velika in tiha je bila cerkev kakor neizmeren grob. (3) Tukaj je kakor v grobu; umrl bi, ko bi tebe ne bilo. (Cankar 1976 knj.10: 28; knj. 11: 139; knj. 12: 104) 
Donadini ${ }^{104}$ i Livadić ${ }^{105}$. Pugelj je kao etalon naveo mrtvačnicu. ${ }^{106}$ Levstik je uz glagol „ćutiti“ upotrebio izraz „kakor grob“107. Imenicu „pogreb“ koju u ulozi etalona vidimo u primerima $4^{\circ}$ i 5 upotrebili su I. G. Kovačić,Vasić i Crnjanski. ${ }^{108}$

\subsection{Nekoliko različitih izraza}

U tabeli 11 navedeni su primeri upotrebe izraza kojima je u njihovom užem kontekstu pripadala različita uloga. Uzvik iz primera 1 nađen je i u Šenoinom delu „Prosjak Luka“ ${ }^{109}$ Kratke izraze kojima se rekapitulira sadržaj teksta koji im prethodi vidimo u primerima 2, 3, $2^{\circ}$ i $3^{\circ}$. I Car je upotrebio sličnu rečenicu. ${ }^{110}$ Reduplikacijom glagola u primerima 4 i $4^{\circ}$ naglašena je tipična promena koja nastupa tokom dijaloga. ${ }^{111}$ Upotreba izraza „ćuti $X$, ćuti $Y$ “ u opisu situacije u kojoj je razgovor zapeo, ostavlja jači dojam nego upotreba izraza poput „zaćutali su“, „nastupilo je ćutanje“. Situacija može da bude napregnuta, neprijatna ponekad za jednu, ponekad za obe strane. Išcekivanje je praćeno psihološkom napetošću. Osobe koje vode dijalog ostaju neko vreme u toj situaciji. A ako do nastavka razgovora uopšte dođe može ga započeti bilo koja od njih.

\footnotetext{
104 (1) Bilo je zagušljivo kao u grobu. (2) I kod mene je bestidno kao u grobu. (Donadini 1968: 50, 66)

${ }^{105}$ Kao u grob, pala je svojom dosele nikad ne osjećanom težinom u barku. (Livadić 1932: 7)

${ }^{106}$ Zunaj na hodniku je bilo vse tiho in mirno kakor v mrtvašnici. (Pugelj 1948: 142)

107 (1) Zaklel se je pri Bogu in Allahu, da hoče molčati kakor grob. (2) Molčala bi kakor grob, ali pa bi naju nalagala (3) Ne rnore je izdati; on molči zdaj kakor grob. (4) meni se lahko zaupaš - molčal bom kakor grob! (5) Ne kliči nikogar [...] in molči kakor grob [...] (Levstik 1913: 65, 72, 405, 555; 1926: 138)

108 (1) O podne navukli se na nebo teški željezni oblaci, a jugo je tulilo žalosno garištem kao na sprovodu. (Kovačić 1983: 63); (2) tako spuštenih očiju, savijene glave, kao pogrebnim korakom, ostavio strašilo. (Vasić 1990b: 285); (3) Neki su, u tim gomilama koračali kao na pogrebu, a drugi kao da igraju. (4) Ušao je u kuću kao da se sa nekog groblja vraćao. (Crnjanski 2002 knj. 1: 80; knj. 2: 370)

109 - Ne! Ne! Ne! - uspriječi se Pavleković bijesan i crven kao rak. (Šenoa 1983 knj. 6: 276)

${ }^{110}$ To ne smije biti! (Car 1926: 161)

${ }^{111}$ In sta molčali in tudi Jure je molčal. (Cankar 1974 knj. 17: 126)
} 
Ivo Andrić

(1) Ne! Ne! Ne! (11: 122; 20: 178)

(2) Vse je mogoče na svetu, ali to ne sme biti mogoče. (24: 242$)$

(3) Dà, iz zavidnosti, to je glavno. (8: 204)

(4) On molči in tudi ona molči, [...]. (9: 80)

(5) Bil je kakor prelomljen v pasu; (23: 115)

(6) Godilo se je z menoj, kakor da me je vodila tuja roka, [...]. (22: 164) $\left(1^{\circ}\right)$ Ne, ne, ne! (2: 300); Ne! Nee! Neee! (9: 164)

$\left(2^{\circ}\right)$ Sve može biti. Ali jedno ne može [...]. To ne može biti. (1: 395)

$\left(3^{\circ}\right)$ Živeti, to je glavno. (15: 107); A to je glavno. (4: 74)

$\left(4^{\circ}\right)$ Šutim ja, šuti Turčin. (6: 108)

$\left(5^{\circ}\right)$ kći Perka opančara [...] utanji se i prelomi u pasu (7: 184)

$\left(6^{\circ}\right)$ svuda po Bosni on je [vezir] vladao tuđom rukom, a ovde [u Travniku] je bio lično (5: 43)

1 - Popótovanje Nikolaja Nikiča i Milan i Milena, 2 - D’Annunzio, 3 - Hudodelec, 4 - Tujci, 5 i 11 - Podobe iz sanj, 6 - Zgodba o nepoštenosti; $1^{\circ}$ - Ekskurzija, $2^{\circ}-$ Na Drini ćuprija, $3^{\circ}-$ Životi, $4^{\circ}-$ Trup, $5^{\circ}-$ Ljubav u kasabi, $6^{\circ}$ - Priča o vezirovom slonu

Tabela 11: Imenice „mrtvac“, „sahrana“, „grob“ kao etaloni poređenja

Andrić je upotrebio i izraze „lomio se u pasu“, „povijen u pasu“112. U opisu mlade ženske osobe koja odrasta, koja se zadevojčila, izrazom „prelomi se u pasu“ nagovestio je mladost i lepotu (primeri $5^{\circ}$ i $6^{\circ}$, tabela 11 ). ${ }^{113}$ Slično su postupili Sremac ${ }^{114}$ i Petrović. ${ }^{115}$ Izraz „prelomljen v pasu“ javlja se u obe verzije teksta „Velika Maša“. ${ }^{116}$ Sličan primer nalazimo i kod Gorkog ${ }^{117}$.

$\mathrm{U}$ primeru $2^{\circ} \mathrm{u}$ tabeli 2 već se pojavio izraz „tuđa ruka“. I u primerima 6 i $6^{\circ} \mathrm{u}$ tabeli 11 upotrebljen u opisu neugodne situacije u kojoj su se likovi našli. „Tuđa ruka“ koja nekoga oblači javlja se i u priči Prežihova Voranca. ${ }^{118}$ Tuđa ruka radi posredno, obično ne onako kao što bi uradio onaj u ime koga se nešto radi ili po čijem se nalogu postupa.

Imenica „kuga“" (primeri 1, 2, $1^{\circ}$ i $2^{\circ}$, tabela 12) koristi se kao etalon u slikovitom opisu vanrednih, opasnih situacija koje među ljude unose nemir i strah. Kuga istrebljuje,

\footnotetext{
112 (1) sve se više lomio u pasu (2) Ova starija žena [...] povijena u pasu, uvek zabrađena, zove se Zuja. (Andrić 1978 knj. 1: 244; knj. 15: 115)

113 Stanka, vitka i snažna devojka, kao prekinuta u pasu, sa čednim i umiljatim licem [...]. (Andrić 1978 knj. 15: 215)

${ }^{114} \mathrm{Kad}$ ide, ona se lomi u struku, sitno korača, a glavu izdiže i pruža je ponosno [...]. (Sremac 2011b: 243)

115 tanka i lomna u struku (Petrović 1964: 61)

${ }^{116}$ Hodil je, kakor da bi bil prelomljen v pasu; [...]. (Cankar 1975 knj. 23: 186)

117 Словно переломившись в пояснице, старуха села, [...]. (Горький 1977 том 10: 155)

${ }^{118}$ Njegovo odelo [...] nije prošila majčina, već nečija tuđa ruka. (Voranc 1990: 49)
} 
(1) Eno samo uro - pa sem že komaj dihal, kakor da je bila kuga vzraku (17: 288)

(2) Kakor da je bila kuga pograbila ljudi ter povodenj opustošila njive. (19: 145)

(3) Cmeri se kakor baba! (18: 9)

(4) Otrok se je zvil v povojih kakor črv [...]. (16: 134)

(5) Kakor živi v mojem spominu, ima rdečo, pisano ruto na glavi, [...]. (9: 204)

(6) In če jutri ne bo denarja, ga sunejo na cesto [...] vsega bo konec [...] kakor Boga vas prosim. (10: 132)

(7) Milost božja, kaj se je primerilo v teh silnih časih! (23: 112)

1 - Za križem: Kovač Damjan, 2 - Krčmar Elija, 3 - Sosed Luka, 4 -Polikarp, 4 - Ob zori: Pred gostilnico; 5 Podobe iz sanj $1^{\circ}$ - Svečanost, $2^{\circ}$ - Anikina vremena, $3^{\circ}$ - Panorama, $4^{\circ}-\mathrm{Kula}, 5^{\circ}-\mathrm{Na}$ vest da je Brusa pogorela, $6^{\circ}-$ Gospodica, $7^{\circ}-$ Ispovijed

Tabela 12: Imenice „mrtvac“, „sahrana“, „grob“ kao etaloni poređenja

pred kugom se bez oklevanja beži. ${ }^{119}$ Imenicu „kuga“ upotrebio je kao etalon poređenja i Matavulj. ${ }^{120}$

Etalon „baba“ (primeri 3 i $3^{\circ}$ ) upotrebljen je u opisu ponašanja jedne osobe, u sastavu izgvorenih reči, pri grubom obraćanju. Slična poređenja pri obraćanju drugoj osobi mogu da budu uvredljive. Dečak je tako doživeo učiteljev prekor (primer $3^{\circ}$ ). Slična

\footnotetext{
${ }^{119}$ Kakor pred kugo beže in koliko se jih vrne? (Cankar 1974 knj. 19: 18)

120 (1) Po Ribniku žalost, kao da je kuga pomorila što je najljepše u njemu. (2) [...] ni od kud ljudskog glasa, kao da je sve kuga pomorila! (Matavulj 2006 knj. 2: 20, 354)
} 
poređenja upotrebili su: Levstik ${ }^{121}, \breve{S}$ imunović $^{122}$, Krleža $^{123}$, Ranković ${ }^{124}$, Tomić $^{125}$, Matavulj ${ }^{126}$, Crnjanski. ${ }^{127}$ Majora sa starom ženom uporedio je Dostojevski. ${ }^{128}$

Etalon „baba“ korišćen je u poređenjima uz glagole „govoriti“, „vikati“, „brbljati“129. Ispred imenice „baba“ ponegde je postavljan atribut. Poređenja u kojima se kao etalon javlja imenica „baba“, ukoliko se upotrebe u slikovitom opisu ponašanja mlađih muškaraca, pogotovo vojnika, situacijama u kojima se očekuju odvažnost i smelost, odražavaju, neodlučnost, slabost, kukavičluk.

Pri upoređenju sa crvom pri slikovitom opisu ponašanja i držanja jednog lika mogu da se uzmu u obzir pokreti koje crv čini, ritmično savijanje, grčenje (primeri 4 i $4^{\circ}$, tabela 12). Tako su i na drugim mestima postupili Cankar ${ }^{130}$ i Andrićc ${ }^{131}$. Upotreba izraza „kao crv“ dolazi uz glagole „grčiti se“, „previjati se “, „bacakati se“, „g(a)mizati“. Bugarski pisac Mihalaki Georgiev takođe je uz etalon „crv“ imao u vidu pokrete tela. ${ }^{132}$

${ }^{121}$ Plešast si, stari, pa govoriš kakor baba, [...]. (Levstik 1926: 75)

122 prisluškivao brbljarije varoške kao nepismena baba? (Šimunović 1952 knj. 1: 413)

123 (1) Čerkezi i Kozaci, smijat će vam se kao babama (2) Što stojiš kao baba? (3) Ispadam kao slinava baba! (4) A što sjedimo do đavola u tami, kao stare babe? (Krleža 1973: 102, 146, 277, 363)

${ }^{124}$ Koješta, kao baba! (Ranković 1952 knj. 2: 390)

${ }^{125}$ Digosmo se kao junaci, a vratit ćemo se kao babe. (Tomić 1970: 59)

126 Šta si mi se tu razbrbljao kao kakva baba! (Matavulj 2006 knj. 2: 435)

127 (1) Гарсули само брбља и прети, као бабе. (2) Vikao je, u sebi, kao neka rasplakana baba, [...]. (3) reče da su ta dva krvnika sedela, kao babe (4) On se bio, kao baba, uplašio (5) proklinje, iz Neoplatense, kao baba. (Crnjanski 2002 knj. 1: 68, 203; knj. 2: 141, 151, 237)

${ }^{128}$ Майор, говорят, ревел, как старая баба, и обливался слезами. Но делать нечего. (Достоевский 1988b: 464)

${ }^{129} \mathrm{U}$ frazeološkom rečniku srpskog jezika navedeno je „brbljati (govorii, pričati) kao <stara > baba - govoriti bez potrebe, brbljati, koješta, govoriti preterano)“ (Otašević 2012: 21)

130 (1) gledal je, kako se je pomikal po mizi tisti debeli rdeči prst, kakor da bi lazil velik črv po papirju (2) Sveženj se je zganil pod pazduho, zvil se krčevito, kakor črv, ki stopi noga nanj. (Cankar 1970 knj. 10: 271; knj. 14: 172)

131 (1) biva, da me prevlada bol, pa se savijam kao crv na zemlji (2) Tu je, naslonivši celo na drvenu ogradu stepeništa i grceci se kao crv, povraćao dugo i na mahove. (Andrić 1978 knj. 11: 68; 15: 299)

132 (1) те са хора, от които е писнал цел народ [...], като чръв се превива (2) Пред големците се превиваше като чърв, лижеше им краката, целуваше им чехлите (3) Кюскията на Мравункьо, от болки се свиваше като черв на жарава. (4) [...] раята ще се превива като чръв под тежкия товар (5) кога натисне мъката и зулумът, та сиротинята се превива като черв край огън (Георгиев 1980: 178, 218, 415, 394, 514) 
$\mathrm{Na}$ sličan način postupali su i Jakšsić1 ${ }^{133}$, Levstik ${ }^{134}$, Veselinović ${ }^{135}$, Vasić ${ }^{136}$, Krleža ${ }^{137}$. Upotreba izraza „viti se (previjati se) kao crv“ upućuje na teško stanje u kom se nalazi neka osoba i njenu inferiornost. U Otaševićevom rečniku upućuje se na lukavost ${ }^{138}$.

$\mathrm{Na}$ više mesta u svom delu Gorki je upotrebio imenicu „crv“ kao etalon poređenja. ${ }^{139}$ Dositej Obradović imao je u vidu sredinu u kojoj crv obitava. ${ }^{140}$ Slično je postupio i Andrić u primerima ${ }^{141} 2^{\circ}$ i $4^{\circ}$ (tabela 12). Šenoa ${ }^{142}$, Kovačić $A^{143}$, Kumičiććc ${ }^{144}$, Novak ${ }^{145}$, Kozarac $^{146}$, Stanković ${ }^{147}$, Matavulj ${ }^{148}$, Nazor ${ }^{149}$, Sekulicíc ${ }^{150}$, Krleža ${ }^{151}$ pri poređenju sa crvom uzeli su u obzir izgled crva, njegov polagan, skriven i uporan rad. Upotreba izraza „kao crv“ dolazi uz glagole „grčiti se“, „previjati se “, „g(a)mizati“, „plivati“, „ra-

${ }^{133}$ Previjala sam se kao crv oko njegovih kolena, padala sam pred njega na zemlju [...]. (Jakšić 1978 knj. 4: 178)

134 (1) Kadar boš stokal strahu v nočeh brez spanja in se boš zvijal v mislili na gotovo pogubo, kakor se zvija črv pod peto brez usmiljenja, [...]. (2) Mene ščiti grožnja Alija Kemala, ki se ga Halil bej boji kakor črv pete; (Levstik 1913: 178, 259)

135 (1) Beše im teško gledati čoveka gde se pred njima kao crv vije. (2) sad, kad ga vidi [...] gde se vije kao crv pred nogama njegovim (3) A kad im staneš oči u oči, oni se viju kao crvi! (Veselinović 1983: 67, 281, 310)

136 (1) Vijem se kao crv, previjam, štipam, [...]. (2) To su strasti što se oko mene vulaju, viju, gmižu kao pravi pravcati crvi (3) gurila i gmizala kao crv i glista (5) On je već vrisnuo, previja se kao crvić, očajno pruža ručice prema meni dok se ja izmičem, [...]. (6) Kao crv, primećeno je, gamiže neprijateljska pešadija sve bliže. (Vasić 1990a: 27, 99; 1990b: 130, 156, 307)

137 miče se kao crv po žljebastim prostorima njene utrobe (Krleža 1966: 403); I vodu crpeš i zahode čistiš i savijaš se kao crv! (Krleža 1973: 361)

${ }^{138}$ U frazeološkom rečniku srpskog jezika navedeno je „viti se (previjati se) kao crv - biti lukav (prepreden, sposoban za pronalaženje izlaza u teškim situacijama“. (Otašević 2012: 1003)

139 (1) Я всю жизнь верчусь, как червь на солнце, а нет мне ни покоя, ни уважения... (2) А моя дорога - поганая и проклятая... не ходят по ней бабы и девки, а, как черви, ползут. . . (3) Илья слушал, и жизнь казалась ему чем-то вроде помойной ямы, в которой люди возятся, как черви. (4) Как черви слепые живут (5) Как враг, она преследует его; как червь, неутомимо точит мозг [...]. (6) голодны, и унижены, и придавлены к земле, как черви в грязи [...]. (7) В углу спряталась железная круглая печка, от неѐ, как толстый червь, труба вверх ползѐт, [...]. (8) Влезет эдакий в душу тебе, подобно червю, и незаметно источит еѐ. (9) Между ними, точно черви, ползают нищие, [...]. (10) Толкались нищие, просовывая грязные ладони, сложенные лодочками, пальцы их шевелились, как толстые черви, [...]. (Горький 1950a: 61, 91, 199, 361, 385; 1950b: 247, 276; 1950c: 142, 224, 559)

140 srce nahodi svoje zadovoljstvo samo u telesnim naslaždenijam, kao crv u đubretu (Obradović 2003: 237)

${ }^{141}$ (1) I predajući se sva tome naporu, udubljivala se unjega, nemo, gluvo, nagonski, kao crv u drvo. (2) Vene Travnik, a u njemu živi još čaršija, kao crv u otkinutoj jabuci. (Andrić knj. 3: 243; 5, 87)

${ }^{142}$ Kao crv kopale su po njegovu srcu (Šenoa 1983 knj. 6: 303)

143 (1) Ta obiteljska tajna poče mi kopati mozgom kao gladan crv mladim dubom. (2) A to čuvstvo štono grize korijenje mladosti poput neviđena crva (Kovačić, A. 1962: 56; 1950: 191)

${ }^{144}$ lonac s rižom [...] čovjek se skoro uznoji, dok uhvati nešto zrnja, koje po njoj pliva kao crvi. (Kumičić 1950 knj. 1: 107)

145 obaraju ih, kao što crv koji se zavukao u žilu obara hrast. (Novak 1951: 291)

146 on će kopati, orati, raditi kao crv, samo da ona nigda ne reče da joj je uz njega teško (Kozarac 1950: 201)

${ }^{147}$ A kad je trezan, radi kao crv. (Stanković 1991: 20)

${ }^{148}$ Jakov i Periša rade kao crvi (Matavulj 2006 knj. 2: 28)

${ }^{149}$ Kupam se, još sitan kao crvić, [..]. (Nazor 1934: 64)

${ }^{150}$ Došli da vide mladića koji je, kažu, radio kao crv, [...]. (Sekulić 1981: 120)

${ }^{151}$ Sve to vrvi u životu amo tamo kao crvi u kvarglu! (Krleža 1938: 68) 
diti“. Kovačić, A., Lovrak, Kumičić, Vasić upotrebili su etalon „crv“ u rečenici u kojoj se javljaju glagoli „zgaziti“, „razdrobiti“, „zgnječiti“. ${ }^{152}$ Etalon crv može da bude upotrebljen i u slikovitom opisu odnosa jedne osobe prema drugoj. ${ }^{153}$ Takvim poređenjima slikovito se opisuje grubo postupanje prema jednoj osobi. Uz imenicu „crv“ javlja se i pridev „slep“. ${ }^{154}$

U primerima 5 i $5^{\circ}$ u tabeli 11 rečenice podsećaju na one koje se javljaju u putopisima i memoarima. U primerima $6,7,6^{\circ}$ i $7^{\circ}$ u pitanju su reči dijaloga i unutrašnjeg monologa. Izraz „kao bog što se moli“, naveden u opisu obraćanja jedne osobe drugoj osobi, javlja se i u delima drugih pisaca. ${ }^{155}$ Tako govori i Kočićev David dok se obraća pisarčiću i sudiji. ${ }^{156}$ Sličan primer nalazimo i u Andrićevom romanu „Gospođica“. ${ }^{157}$

\section{Zaključak}

Poredbene konstrukcije i kraći izrazi upotrebljeni u opisu likova i objekata, izdvojeni proznih književnih dela Ivana Cankara i Ive Andrića posmatrani su u ovom radu u užem kontekstu, u tekstu koji nije duži od jedne ili dve susedne rečenice. To su „jaka“ poređenja“ i izrazi kojima se na sličan način upečatljivo opisuje lik ili neki objekat. $\mathrm{U}$ pitanju su elementi tehnike pripovedanja čija se primena odlikuje retkošćc kako u Cankarevom tako i u Andrićevom delu. Očigledno je da su pisci vodili račna o tome da javljanje takvih elemenata u tekstu u ukupnom delu ograniče na mali broj, po pravilu izbegavajući ponavljanje u istom delu. Često je u pitanju zapažanje o jednom liku koji se nalazi u situaciji koja je za njega nepovoljna, ponekad neizvesna i rizična, i u kojoj se on obično oseća inferiorno. Zaslužuje pažnju i celovitije sagledavanje upotrebe pojedinih izraza uzimajući u obzir i širi kontekst, ponegde i delo u celini.

Slični primeri upotrebe poređenja i izraza nađeni su i u delima drugih južnoslovenskih pisca, kao i u delima ruske klasične književnosti. Uvećanjem broja primera, kada su poređenja u pitanju, bilo je moguće otkriti druge elemente teksta koji ih prate. Pre svega, glagole čija je upotreba tipična u rečenicama u kojima se javljaju pojedina poređenja. $U$ uvećanom skupu primera do izražaja je došla sličnost upotrebe posmatranih poređenja

152 (1) Zgazite svoga roba kao crva! (Kovačić, A.1950: 112); (2) Zgnječili bi ga kao crva! (Lovrak 1989: 103); (2) učinite me najsretnijim čovjekom ili me zgazite kao jadna crva! (Kumičić 1950 knj. 1: 201); (3) kako bih ga razdrobio, rastrgao, zgazio kao crva (Vasić 1990b: 95)

${ }^{153}$ [...] jaz sem mu že pisal, da je zame, kakor črv na cesti. (Cankaar 1970 knj. 10: 91)

154 Потом их стало много и они густо и жирно зароились, слепые, как черви. (Пастернак 2011: 49)

155 (1) Nauči me, kao boga te molim! (2) Kao boga te molim, reci mi, jesi li ga ubio? (Veselinović 1983: 217 280); (3) Ali ja te molim, kao što se bog moli! (Lazarević 2011: 125); (4) Molim te kao Boga, ostavi me na miru. (Vasić 1990b: 86); (5) ja sam ga kao Boga molila, da mi oprosti (Kozarac 1950: 413)

156 (1) Dijete, molim te kô što se Bog i stariji mole, ne prekidaj me u riječi! (2) Molim te, glavati gospodine, kô što se Bog i stariji mole, drž' se samo reda i zakona! (Kočić 2002: 90, 99)

${ }^{157}$ Gospođice, ovako vas molim, sklopljenih ruku, kao bog što se moli. (Andrić 1978 knj. 3: 67) 
i izraza u nekoliko slovenskih jezika, sličnost koja je ostavila traga u književnim delima jednog dužeg istorijskog razdoblja.

\section{Prilog 1. Pisci}

Ruski pisci: Nikolaj Gogolj (1809-1852), Mihail Ljermontov (1814-1841), Ivan Gončarov (18121891), Ivan Turgenjev (1818-1883), Fjodor Dostojevski (1821-1881), Lav Tolstoj (1828-1910), Anton Čehov (1860-1904), Maksim Gorki (1868-1936), Leonid Andrejev (1871-1919), Aleksandar Kuprin (1870-1938), Николай Лесков (1831-1895), Mihail Bulgakov (1891-1940), Boris Pasternak (1890-1960), Bugarski pisci: Ivan Vazov (1850-1929), Mihalaki Georgijev (1854-1916), Jordan Jovkov (1880-1937), Srpski pisci: Đura Jakšić (1832-1878), Milovan Glišić (1847-1908), Dositej Obradović (1739?-1811), Simo Matavulj (1852-1908), Janko Veselinović (1862-1905), Svetolik Ranković (1863-1899), Ivo Ćipiko (1869-1923), Radoje Domanović (1873-1908), Miloš Crnjanski (1893-1977), Veljko Petrović (1884-1967), Bosanskohercegovački pisci: Petar Kočić (1877-1916), Hamza Humo (1895-1970), Bosanskohercegovački pisci: August Šenoa (1838-1881), Šandor Ksaver Đalski (1854-1935), Antun Gustav Matoš (1873-1914), Dinko Šimunović (1873-1933), Ivana Mažuranić-Brlić (1874-1938); Branimir Livadić (1871-1949), Miroslav Krleža (1893-1981), Ante Kovačić (1854-1889), Vjenceslav Novak (1859-1905), Ulderiko Donadini (1894-1923), Josip Kozarac (1858-1906), Ivan Goran Kovačić (1913-1943), Viktor CarEmin (1870-1963); Slovenački pisci: Ivan Tavčar (1851-1923), Vladimir Levstik (1886-1957), Janko Kresnik (1852-1897), Fran Zbašnik (1855-1935), Prežihov Voranc (1893-1950), Josip Jurčič (1844-1881), Milan Pugelj (1883-1929), Franc Ksaver Meško (1874-1964)

\section{Prilog 2. Izvori}

Ruski pisci: Андреев, Л. Н. (1971) Повести и рассказы в двух томах, Художественая литература, Москва; Гоголь, Н. В. (2014) Петербургские повести, Азбука, СанктПетербург; Гоголь, Н. В. (2009а) Мертвые души, Белый город, Москва, Гоголь, Н. В. (2009b) Тарас Булъба у: Миргород, Белый город, Москва Гоголь, Н. В. (2009с) Вечера на хуторе близ Диканьки, Белый город, Москва; Гончаров, И. А. (2015) Обрыв, Азбука, Санкт-Петербург; Гончаров И. А. (1958) Обрыв: Роман в пяти частях. Государственное издательство, художественной литературы. Москва; Гончаров, И. А. (1999) Обыкновенная история, Эксмо, Горький, М. (1950а) Повести 1900-1906, ИМЛИ, РАН, Москва; Горький, М. (1950b) Повести 1907-1909, ИМЛИ, РАН, Москва; Горький, М. (1950с) Жизнь Матвея Кожемякина: Повести 1909-1912, ИМЛИ, РАН, Москва; Горький, М. (1971) Полное собрание чочинений в двадцати пяти томах, Наука, 1971-1975; Достоевский, Ф. (1972) Чужая жена и муж подкроватью, Повести и расказы, Наука, Ленинград Достоевский, Ф. (2012а) Братъя Карамазовы, Эксмо, Москва; Достоевский, Ф. (2012b) Бесы, Эксмо, Москва; Достоевский (2012c) Преступление и наказание, Эксмо, Москва; Достоевский, Ф. (2011а) Игрок, Эксмо, Москва; Достоевский, Ф. (2011b) Подросток, Эксмо, Москва; Достоевский, Ф. (1990) Вечный мужи: Собрание сочинений; т. 8, Наука, Ленинград; Достоевский, Ф. (1998) Бедные люди; Белые ночи; Неточка Незванова, ТЕЕРА, Москва; Достоевский, Ф. (1988а) Село Степанчиково и его обитатели: Собрание сочинений; тот. 3, Наука, Ленинград; Достоевский, Ф. (1988b) Записки из мертвого дома, Собрание сочинений, том 
3 Наука, Ленинград; Куприн А. (1964) Собраниесочинений в девяти томах, Огонек, Москва; Куприн, А. (1976) Поединок, Карелия, Петрозаводск. Лермонтов, М. (1977) Герой нашего времени, Советская руссия, Москва; Лермонтов, М. Ю. (1989) Полное собрание стихотворений в два тома, Сов. Писатель; Лесков, Н. С. (1957) Запечатленный ангел Собрание сочинений, том 4, Художественая литература, Москва, Лесков, Н. С. (1973) Собрание сочинений в 6 томах, Правда, Москва; Пастернак, Б. (2011) Пхранная грамота, Астрель, Москва; Пушкин, А. С. (2016) Повести Белкина, Азбука, Санкт-Петербург; Толстой, Л. Н. (2009) Повести и расказы, Белый город, Москва; Тургенев, И. С. (2011а) Отци и дети, Рудин, Накануне, Эксмо, Москва; Тургенев, И. С. (2011b) Дворянское гнездо, Азбука, Санкт-Петербург; Тургенев, И. С. (2012) Первая люубовъ, Вешние водъ, Эксмо, Москва; Тургенев, И. С. (2013) Муму: повести, рассказы, Эксмо, Москва; Тургенев (1981) Дым, том 7, Сочинени Наука Москва; Тургенев, И. (1982) Новъ, Сочинени Повести и разказы, том 9, Наука Москва; Тургенев, И. (1982) Щи, Стихотворения в прозе, том 10, Наука Москва,Тургенев, И. С. (1981) Полное собрание сочинений и писем в тридцати томах том 9, Наука, Москва 1981; Чехов, А. П. (1999а) Драма на охоте, Рассказы 1883-1886, АСТ Фолио. Харьков; Чехов, А. П. (1999b) Скука жизни, Рассказы 1885-1886, АСТ Фолио. Харьков; Чехов, А. П. (1999с) Дама с собачкой, Рассказы 1887-1899, АСТ Фолио. Харьков; Чехов, А. П. (1999d) Рассказы, повести, юморески: 1880-1882, Собрание сочинений том 1 , ТЕРРА; Москва; Чехов А. П. (1976) Полное собрание сочинений 1974-1982 Наука, Москва; Bugarski pisci: Вазов, И. (1956) Събрани съчинения, Български писател, София; Георгиев, М. (1980) Меркгт на чичо Денчо, Избрани творби БЗНС София; Йовков, Й. (1983) Събрани съчинения, Български писател, София; Пелин, Е. (1977) Събрани съчинения в шест тома, Български писател, София; slovenački pisci: Cankar, I. (1967-1976) Zbrano delo, Državna založba Slovenije Ljubljana; Cankar, I. (1956) Slike iz snova, Rad, Beograd; Cankar, I. (1981) Proza, Matica srpska, Novi Sad; Cankar, I. (2006) Gospa Judita, Beograd; Levstik, V. (1924) Deček brez imena in druge zgodbe, Tiskovna zadruga, Ljubljana; Levstik, V. (1966) Hilarij Pernat, Delo, Ljubljana; Levstik, V. (1958) Gađe gnezdo, Zapiski Tine Gramotnove, Cankarjeva založba, Ljubljana; Levstik, V. (1907) Pigmalion, Sirota Jerica, Zabavna knjižnica, Slovenska Matica; XIX. zvezek, Ljubljana; Levstik, V. (1913) Za svobodo in ljubezen roman z Balkana, Slovenski ilustrovani tednik, Ljubljana. Levstik, V. (1926) Pravica kladiva, Vodnikova družba, Ljubljana; Levstik, V. (1913) Za svobodo in ljubezen, Učiteljska tiskarna, Celje; Meško, K. (1907) Drama izza davnih dni, Zabavna knjižnica, Slovenska Matica, XIX zvezak; Meško, K. (1954) Izabrano delo, prva knjiga, Družba Sv. Mohorja, Celje; Pugelj, M. (1948) Zbrane novele, Slovenski knjižni zavod, Ljubljana; Voranc, P. (1990) Đurđevak, Zavod za udžbenike, Novi Sad; Kresnik, J. (2012) Ocetov greh, El-knjiga, Genija, Ljubljana; Jurčič, J. (2012) Lepa Vida, El-knjiga, Genija, Ljubljana; Zbašnik, F. (1893) Na krivih potih: Povest, Slovenske večernice XLVII, Družba sv. Mohorja v Celovecu; srpski, hrvatski, bosanskohercegovački pisci: Andrić, I. (1976) Sabrana dela, Prosveta; Beograd; Andrić, I. (1981) Sabrana djela, Svjetlost, Sarajevo; Begović, M. (1965) Giga Barićeva, knj. 1, 2 i 3, Zagreb; Brlić-Mažuranić, I. (1926) Priče iz davnine, Matica hrvatska Zagreb, BrlićMažuranić, I. (1989) Jaša Dalmatiu pothralj Gudžerata, Mladost, Zagreb; Car-Emin, V. (1926) Nove borbe, SKZ, Beograd; Ćipiko, I. (1951) Sabrana dela, Prosveta, Beograd; Crnjanski, M. (2002) Druga knjiga seoba, Zavod za udžbenike i nastavna sredtava, Beograd; 
Domanović, R. (1974) Satire, Nolit, Beograd; Đalski (1964) Pod starim krovovima, Pripovjesti, Zora, Matica hrvaska, Zagreb; Donadini, U. (1968) Novele, romani, drame, kritike, eseji, Znanje, Zagreb; Humo, H. (1955) Hadžijin mač, Svjetlost, Sarajevo; Lazarević, L. (2011) Izabrane pripovetke, Evro-Giunti, Beograd; Lazarević, L. (2011) Švabica i druge pripovetke, Imperija knjiga, Kragujevac; Lovrak, M. (1989) Vlak u snijegu, Svjetlost; Sarajevo; Jakšić, Đ. (1978) Sabrana dela, knj. 3 i 4, Beograd; Kozarac, J. (1950) Djela, Zora, Zagreb; Kočić, P. (2002) Sabrana djela, knj. 2: Besjeda, Banja Luka, Kovačić. I. G. (1951) Izabrana djela, Glas rada, Zagreb; Kovačić. I. G (1983) Proza I, Matica hrvatska, Zagreb; Kovačić, A. (1950) Djela I, Zora, Zagreb; Kovačić, A. (1965) U registraturi, Nolit, Beograd; Krleža, M. (1938) Knjiga proze, Biblioteka nezavisnih pisaca, Zagreb; Krleža, M (1973) Hrvatski bog Mars, Nolit, Beograd; Kumičić, E. (1885) Sirota, Matica hrvatska, Zagreb; Kumičić, E. (1950) Djela I i II, Zora, Zagreb; Livadić, B. (1932) Novele, novi izbor, Matica hrvatska, Zagreb; Matavulj, S. (2007) Sabranadela u devet knjiga, Zavod za udžbenike i nastavna sredstva, Beograd; Matoš, A. G. (1953) Sabrana djela, svezak 1 i 2, JAZU, Zagreb; Matoš, A. G. (1967) Ljubav i dubljina, Zora, Zagreb; Nazor, V. (1934) Andeo u zvoniku, u: Moderni hrvatski pripovjedači, Minerva, Zagreb; Novak, V. (1951) Djela I, Zora, Zagreb; Obradović, D. (2003) Basne, naravoučenija, Divit, Beograd; Petrović, V. (1964) Zemlja, Rad, Beograd; Ranković, S. (1952) Gorski car, Seoska učiteljica, u: Sabrana dela I, Prosveta, Beograd; Ranković, S. (1952) Porušeni ideali, u: Sabrana dela II, Prosveta, Beograd; Sremac, S., (2011a) Pop Ćira i pop Spira u: Deset vekova srpske književnosti: Stevan Sremac, Matica srpska, Novi Sad; Sremac, S. (2011b) Zona Zamfirova u: Stevan Sremac, Matica srpska, Novi Sad; Sremac, S. (1987) Suterenski stanovnici, pripovetke, Bratstvo-Jedinstvo, Novi Sad; Stanković, B. (1991) Uvela ruža idruge priče, IP „Beograd“, Beograd; Sekulić, I. (1981) Kronika palanačkog groblja, Prosveta, Beograd; Šimunović, D. (1952a) Djela I: Pripovjetke, Mladost, Zagreb; Šenoa, A. (1983) Sabrana djela, Globus, Zagreb; Tomić, J. E. (1970) Opančareva kći, Zmaj od Bosne, Melita, Matica hrvatska, Zora, Zagreb; Uskoković, M. (1979) Sabrana dela, Kadinjača, Užice; Veselinović, J. (1983) Hajduk Stanko, Nolit, Beograd; Veselinović, J. (19??) Celokupna dela, Beograd; Vasić, D. (1990a) Crveme magle, Izabrana dela, knj. 1; Prosveta, Beograd; Vasić, D. (1990b) Sabrane pripovetke, Izabrana dela, knj. 2; Prosveta, Beograd.

\section{Literatura}

Аристова, Т. С. 1995. Словарь образных выражений русского языка. Москва: Отечество.

Cankar, I. 1968. Leposlovje, eseji, kritika. prva knjiga. Ljubljana: Slovenska matica.

Đukić, B. 1977. „Socialni motivi v delih Ivana Cankarja, Stefana Mitrova Ljubiše in Petra Kočića.“ In Simpozijum o Ivanu Cankarju, Ed. Josip Vidmar, Štefan Barbarič i Franc Zadravec, 203-212. Ljubljana: Slovenska matica.

Israel, M., Harding, J. R., and Tobin, V. 2004. „On simile.“ In Language, culture and mind, Eds. M. Achard and S. Kemmer, 123-135. Stanford: CSLI Publications.

Keber, J. 2011. Slovar slovenskih frazemov. Ljubljana: Založba ZRC, ZRC SAZU.

Kraft, B. 1969. „Cankar in ruska književnost.“ Slavistična revija (1): 45-98. 
Menac, A., Fink-Arsovski, Ž. I Venturin, R. 2003. Hrvatski frazeološki rječnik. Zagreb: Naklada Ljevak.

Мокиенко, В. М. 1989. Славянская фразеология. Москва: Высшая школа.

Nabergoj, I. A. 2015. „Iskanje resnice v literaturi: etični izzivi literarnih junakov v delih Cankarja, Tolstoja in Dostojevskega. “ Edinost in dialog (70): 65-74.

Ничева, М. 2002. Фразеологичен речник на бглгарския език. Пловдив: Хермес.

Otašević, Đ. 2012. Frazeološki rečnik srpskog jezika. Novi Sad: Prometej.

Ožbalt, M. A. I. 1978. „Ivan Cankar and Morley Callaghan: a study in contrastive parallelism.“ Slovene Studies Journal: 45-66.

Платонова, Т. В. 2011. Место сравнений в художественной речи А. И. Куприна. Записки Орловского государственного университета. Серия: Гуманитарные и социальные науки.

Slovar slovenskega knjižnega jezika, Inštitut za slovenski jezik, SAZU, http://bos.zrc-sazu.si/cgi.

Šolak, Z. 2004. „Likovi u Andrićevom delu i problem s bojom lica.“ Zbornik Matice srpske za knjižeunost i jezik (57): 103-135.

Телия, В. Н. 1996. Русская фразеология. Москва: Школа „Языки русской культуры“. Verč, I. 1977. „Cankar in Dostojevski.“ Sodobnost (7): 764-768.

Vučenov, D. 1977. „Jernejevi dijalogi s svetom, v katerem živi, kot pomemben Cankarjev umetniški dosežek. "In Simpozijum o Ivanu Cankarju, Ed. Josip Vidmar, Štefan Barbarič i Franc Zadravec, 188-195. Ljubljana: Slovenska matica. 